\title{
Filmmaking as a source of enhanced knowledge and transformation in conflicts over small-scale fisheries: the case of Colombia
}

\author{
$\underline{\text { Beatriz Rodriguez-Labajos }}^{1,2}, \underline{\text { Lina M. Saavedra-Díaz }}^{3}$ and $\underline{\text { Darlin Botto-Barrios }}^{3}$
}

ABSTRACT. Small-scale fisheries (SSF) harvesting on coastal and inland aquatic ecosystems sustain the livelihood of hundreds of millions around the world. In Colombia, as in many other developing countries, SSF suffer from multiple pressures and conflicts. Yet the research on SSF conflicts is scarce and the typology of these conflicts is poorly systematized and understood. Existing studies lack the necessary interdisciplinary integration to address social-ecological processes involved in SSF. Moreover, scientific research requires building trust with fishers in order to gain an accurate picture of relevant intra-community processes and values.

In face of this situation, we compiled information from nonfiction films about fishing conflicts, with the double aim of underpinning scientific knowledge on conflicts over SSF and analyzing the use of the films to promote transformations in these conflicts. Our empirical evidence relies on the organization of an ad hoc docu-conference where filmmakers, fishers, and the general public engaged in a meaningful discussion on the issues affecting SSF communities in Colombia.

Films represent the range of conflicts over SSF in 31 locations of 16 Colombian departments and provide data about types of actors involved in the conflicts, types of conflicts and their causes, and possible courses of action. We gained insights into fishing conflicts as processes of change that involve drivers and impacts with common patterns in both inland waters, and marine and coastal environments but evolve in diverging responses or calls for action. Beyond the variables emerging in the films, audiovisual content supports stakeholders in their pursuit of knowledge sharing, political mobilization, and social functioning. Films about SSF conflicts expand knowledge and relatedness that propel intellectual processes tending to exacerbate the conflict and/ or stimulate sense of place, enhance governance, and give a boost to alternatives. Research participants (filmmakers, fishers, and the public) discussed advantages and limitations of using films to tackle the SSF crisis in Colombia. We demonstrate the value of films in social-ecological research and provide evidence of how they can support and bring about transformative change.

Key Words: Colombia; creative research methods; environmental conflicts; filmmaking; fishing conflicts; small-scale fisheries

\section{INTRODUCTION}

Small-scale fisheries (SSF) harvesting on coastal and inland aquatic ecosystems sustain the livelihood of approximately 108 million people in developing countries (Kelleher et al. 2012, Salas et al. 2018). Hence, the United Nations recognizes and protects access rights to SSF through the Sustainable Development Goal (SDG) 14.b.1, although fisheries are somehow linked to all seventeen SDGs (Franz 2018). In Colombia, as in many other middle-income countries, artisanal fishing communities suffer pressures from multisectoral stressors (Salas et al. 2007), which intensify the tensions involved within fishing operations (Pauly et al. 2002).

Literature on SSF conflicts typically bring the ecological or biological dimensions of fisheries to the core of the discussion (Arthur et al. 2015). Specific socioeconomic or political challenges small-scale fishers face have received less attention (Bavinck et al. 2018). Fishers are one among many types of actors enduring adverse effects of processes such as urban encroaching and urban waste pollution (Islam and Tanaka 2004, Vikas and Dwarakish 2015, Chouhan et al. 2017), the expansion of industrial agriculture (Mateo-Sagasta et al. 2017), or direct violence from illegal activities or civil conflict (Bavinck et al. 2018, Scholtens and Bavinck 2018). In turn small-scale fishing puts pressure on inland waters and marine environments through, e.g., overfishing (Salas et al. 2007), use of inadequate fishing practices (FAO 2009), and lack of governmental surveillance or control (Pitcher et al. 2006, 2009).

Over time, fisheries conflicts have increased in frequency and intensity in different parts of the world (Spijkers et al. 2018). Recent studies acknowledge the intensified global struggles in the fishing sector and the distributional justice issues fishers face (Ratner et al. 2014, Song and Soliman 2019). The decrease of fishing resources, the increase of sea food demand, and illegal fishing are some of the triggers of conflicts affecting the peace and stability in marine and continental waters. As a result, new databases (e.g., EJatlas 2020 https://www.ejatlas.org/, Secure Fisheries Program 2020 https://securefisheries.org/) seek to understand and mitigate the causes of global patterns of fisheries conflict (Spijkers et al. 2019).

Yet the very definition of fisheries conflict is imprecise, given the diversity of the fishing sector, and the conflicts around SSF are poorly systematized and understood (Spijkers et al. 2018). Undoubtedly, the role of SSF in the governance of coastal and marine and freshwater ecosystems is crucial (Pomeroy et al. 2007, Coulthard et al. 2011). However, existing studies come up against the need to ensure interdisciplinary integration of socialecological processes involved (Sowman 2011, Pfaff et al. 2019). Scientific research on sensitive issues such as violence against

${ }^{1}$ University of California, Berkeley, Energy and Resources Group, USA, ${ }^{2}$ Universitat Automa de Barcelona, Institut de Ciència i Tecnologia Ambientals, Spain, ${ }^{3}$ Grupo de Investigación en Sistemas Socioecológicos para el Bienestar Humano, Department of Biology, Universidad del Magdalena, Colombia 
fishing communities, corruption, or environmental crimes is not easy. Such studies require building trust with fishers so as to gain an accurate picture of relevant intra-community processes and values (Matera 2016). At the same time, fishers are one more case of engagement fatigue (Sterling et al. 2017), after recurrent research interventions through interviews, questionnaires, or focus groups.

In this context, ecological research initiatives are turning to innovative and creative tools for the analysis and dissemination of social-ecological knowledge (Velez and Lopez 2013, SaavedraDíaz et al. 2015, Lima et al. 2016). Researchers increasingly involve alternative sources of information (such as newspapers, legal cases, and films) in their approach to the communities. This is particularly valuable when the research aims engage with the concerns of social movements and communities that are not used to the traditional avenues of academic research (Ratner et al. 2014, Bavinck et al. 2018). The actual value of these creative avenues to enhance research about fisheries conflicts, and more broadly for socio-environmental conflicts, is yet to be assessed.

Our investigation explores this gap guided by two interconnected aims. The first is to improve knowledge about conflicts over SSF in Colombia building on a systematic examination of audiovisual materials. The second consists of analyzing the ways in which this form of knowledge generation contributes to improving the situation of the actors involved in these conflicts, especially small-scale fishers.

In this paper we review the existing literature about SSF in Colombia and about the use of films to improve knowledge and governance of aquatic environments. We did not engage ourselves in film production for the purpose of this study. Our empirical evidence relies on the systematic compilation of audio-visual materials via the organization of an ad hoc "docu-conference" where filmmakers, fishers, and the public engaged in a meaningful discussion of the environmental justice issues affecting SSF communities in Colombia.

\section{BACKGROUND}

\section{An overview of small-scale fisheries in Colombia}

Territorial heterogeneity and associated socio-cultural diversity shape Colombia's megadiversity. Understanding such a complexity is a prerequisite for any environmental, economic, or social decision made in the country (Carrizosa Umaña 2014). The fishing sector is a foremost example. At the marine level, fishing takes place on two coastlines, the Caribbean Sea and Pacific Ocean, as well as in insular areas (De la Hoz et al. 2015, Acero and Polanco 2017). Inland waters fishing occurs in five main hydrographic basins: Magdalena, Sinú, Atrato, Orinoco, and Amazonas (Mojica et al. 2012, De la Hoz et al. 2015). Although marine fishing involves both small scale and industrial sectors, fishing in continental freshwaters is essentially small-scale (De la Hoz et al. 2015).

Colombia has registered 4200 fish species in either marine or inland waters, that is, $12 \%$ of the world's fish richness (Acero and Polanco 2017). This positions Colombia as one of the countries with the highest fish diversity worldwide (Andrade 2011). Yet, as happens in tropical zones, fish populations occur at relatively low abundance (Stuart-Smith et al. 2013). Moreover, fish species suffer pressures both on the Caribbean and Pacific coastlines, most notably overexploitation of fishery resources, habitat destruction, and pollution (Acero and Polanco 2017, Chasqui et al. 2017). Likewise, poor fisheries policies hit the fishing activity in both coasts, as lack of regulation or law enforcement converge with insufficient surveillance and control (Saavedra-Díaz et al. 2015). Meanwhile, fishery resources in inland waters suffer from the disproportionate growth of economic sectors such as mining, hydropower, and agroindustry (Mojica et al. 2012, AUNAP and Unimagdalena 2014).

In general, the fisheries in both inland and marine waters suffer three main problems: unsustainable use of fishery resources, lack of planning, and weak governance systems (FAO and MinAgricultura 2014). Additionally, Colombian fishers have been victims of the civil conflict in the country. In fact, the violation of their human rights is regarded as a prime root of the problems faced by this sector (Saavedra-Díaz and Jentoft 2017).

Despite the vulnerabilities and risks associated to fishing, between 150 to 190 thousand small-scale fishers operate in Colombia, either in inland waters (two-thirds of all fishers) or in marine waters (the remaining third), and consider their daily livelihood depends mainly on fishing (Rueda et al. 2011, Esquivel et al. 2014). Locally, fishing is an important source of employment that sustains food security and nutrition security in rural areas (AUNAP and Unimagdalena 2014, OEDC 2019).

\section{Filmmaking and knowledge on environmental change and} governance in aquatic environments

Researchers are well aware of the need to bridge a gap in public communication of science (Peters 2013). Filmmaking, and especially the documentary genre, has been a preferred avenue for the popularization of science, progressively moving from being a tool for the transmission of scientific findings to a space of participation in science and knowledge integration (Gouyon 2016). Films are well suited to articulate complex narratives of environmental change and governance (Cumming and Norwood 2012). For example, film has been used to promote awareness and concerns about conservation needs in fields ranging from wildlife (Blewitt 2011, Gouyon 2016), cultural heritage sites (Pan and Ryan 2013), and the urban green (Ozduzen 2018).

The management of aquatic ecosystems, and fisheries specifically, is an important case in point. The first film by John Grierson, who coined the term "documentary," was "Drifters" (1929), a portrayal of the workers in the herring fishery in Britain. The film "The Cove" (2009) drew international attention to the dolphin hunt in the Taiji National Park, Japan. Likewise, "Darwin's Nightmare" (2004) denounced environmental and social impacts of Nile Perch fishing in Lake Victoria, Tanzania. The disturbing audio-visual project "Leviathan" documents the toll of largescale industrial fishing on both the suffering of the fish and the brutalization of humans for the benefit or urban-driven economies (Arboleda and Banoub 2018). These films sparked controversy and generated debates about which points of view were represented, and which were excluded. Yet they serve as examples of how different currents of environmentalism (Guha and Martinez-Alier 1997) can be portrayed also through filmmaking. 
Drama films have also long taken notice of the livelihoods of fishers. The Italian film "La Terra Trema" (The Earth Trembles, 1948) by Luchino Visconti, or the Southern Asian movie "Thirai Kadal" (The Chasm, 2017) by Janaki Viswanathan, allowed audiences to witness the relationships between fishers and nature, and conflicts around interests in fisheries. Thus fisheries management emerges as a matter of social struggle and justice that urges the adoption of a social science approach (Bavinck et al. 2018).

In fact, social and indigenous movements worldwide use films along with other artistic manifestations, e.g., music, poetry, or painting, in their repertoire of contention (Wiebe 2015, Vasudevan and Kearney 2016). A prime example around the management of SSF is the Too Big To Ignore "SSF Virtual Art Festival" that aims to bring awareness about issues and challenges faced by communities, organizations, and researchers working on this topic (http://toobigtoignore.net/share-your-talents-at-ssfvirtual-art-festival-june-8/).

Clearly, the use of films is a fundamental part of both informal and formal environmental education, especially for adults (Clover 2011). In addition, films help to overcome representation issues through counterhegemonic narratives that provide visibility and help to gain support for powerless movements (Gunn and Horvath 1987, Ozduzen 2018). This does not equate with sensationalistic attention-seeking until the next spectacular image arrives (Heissenbüttel 2014). Rather, films have become strategic pathways for dissemination and awareness about environmental justice conflicts. Yet, despite the increased recognition of filmmaking in scientific research and the ample use of films in grassroots processes around fishing, the scientific literature lacks a systematic examination of film materials about conflicts over SSF.

\section{METHODS}

\section{Data gathering}

Inspired by Curtis et al. (2012), we compiled empirical data about visual arts of interest for conservation through a conference organized for that purpose. The docu-conference "Documentaryfilms for Environmental Justice: environmental conflicts associated with SSF marine-coastal and continental fisheries" was held at the University of Magdalena, Santa Marta, Colombia, on 2-3 May 2018. The event program relied on a national open call for audio-visual materials about environmental conflicts that affect the SSF sector in Colombia. The event aimed at facilitating a space for reflection about this topic mediated by audio-visuals and multimedia methods, i.e., documentaries, animation, photo exhibitions, and interactive platforms. The call made explicit our aim to explore the use of documentary films as a research tool to reveal conflicts, visualize the actors' roles in the conflicts, and promote transformations toward sustainable fisheries management.

Besides supporting the preparation of the conference, the purpose of the call was compiling three types of data on each piece of audio-visual material from the producers or users themselves: (1) technical information about the piece (location, production date, type of audio-visual material, awards, and organizations involved in the production); (2) data about the reported fisheries conflicts; (3) purpose of the piece. Given the lack of a precise definition of fisheries conflict in the literature, we adopted a bottom-up working approach, directly asking the participants to submit materials that reflected conflicts over small-scale fisheries and shaping a conceptualization from their inputs. Therefore, we accepted as a fisheries conflict anything regarded as such by the people directly involved.

The online submission form was amply circulated among different channels of potentially interested groups, fishers' societies included. Of 29 items submitted, 20 fit the objectives of the call ( 10 coastal-marine fisheries and 10 continental fisheries) and were included in the final program of the conference (Appendix 1).

The event involved 56 registered participants across different institutions (universities: 28, NGOs: 10, fisher's organizations: 15, other). Thus, different types of knowledge and expertise interacted. Representatives from fishing communities, fishers' organizations, and NGOs appealed to traditional and local forms of knowledge. Professionals from institutions involved in the fishing sector and universities approached discussions from a technical and scientific stance.

The social media live streaming received $\sim 3600$ hits during the days of the event. During the conference, each piece was projected after a presentation of the director/producer or their representative (20 to 30 minutes). The pieces were grouped thematically in blocks of three to four pieces, basically organized around types of fisheries, coastal-marine and continental. Each block gave ample time for public discussion. The discussions during the conference were video- and audio-recorded and transcribed, after explicit notice to and authorization by participants. Detailed proceedings of the event were distributed and validated by all participants.

\section{Data organizing and analysis}

Qualitative data analysis of each piece involved coding to identify the following: (a) type of fisheries conflict referred to in the piece; (b), ecosystem and species affected; and (c) operating drivers (principal and secondary), impacts of the conflict, responses in the conflict. The transcripts of the public discussions, along with the information supplied during the registration stage provided data about the purpose of the piece, the way it was used in the conflict, its limitations, and recommendations for improved impact. This data was also coded. Cross checking of coding and the creation of a unified codebook underpinned the reliability of the data organization process.

Therefore, the content of the pieces, the presentations of the filmmakers, and the discussions around each piece constituted the empirical basis for the analysis. The two research aims guided the reasoning, supported with descriptive statistics (frequency analysis) and geographic representation of results, using ArcGIS ${ }^{\circledR}$ software by Esri. A visual representation of code structures about purposes of film production and stakeholders made use of the social network software Gephi 0.9.2 (Bastian et al. 2009). Certain codes within the network were relatively more closely connected to each other. We used modularity analysis to identify and represent such tightly knit groups of codes. Modularity is a measure of community structure in the network, integrated into the statistics panel in Gephi, that detects significant differences in the number of links between the analyzed network and a random network: significantly less links between groups, and more links within groups (Newman 2006). Nodes with the same 
Fig. 1. Location of the conflicts reported in the films. Source: Questionnaire to film producers and content of the films.

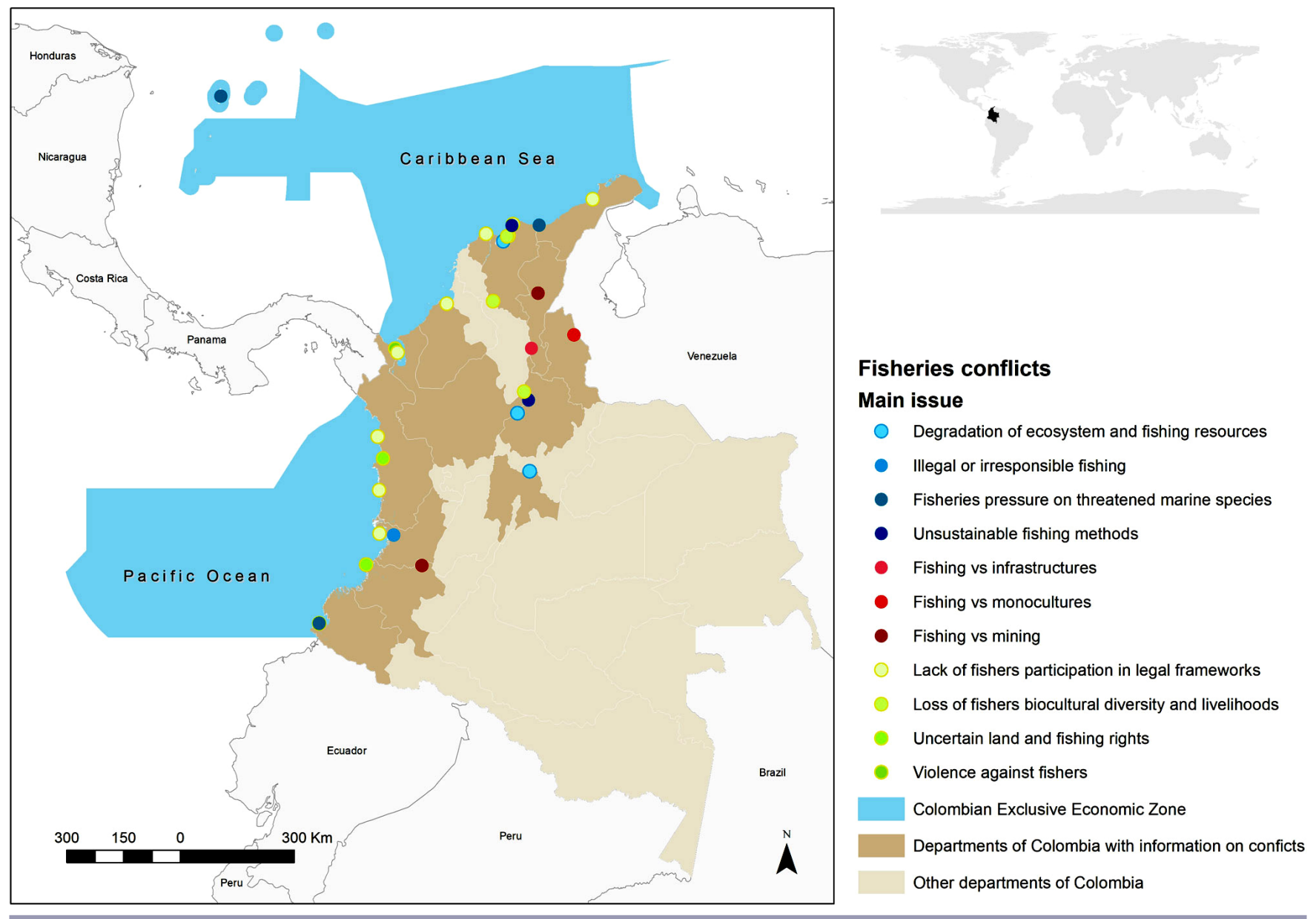

modularity class constitute a community of terms with the network of codes. To make these communities visible, we displayed them in a circular layout using modularity classes as a partition value, a method recommended to visually detect communities in networks (Blondel et al. 2008). Then we used the results in the reasoning.

\section{RESULTS}

Films represent the range of conflicts over small-scale fisheries Figure 1 presents the map with 31 locations distributed along 16 Colombian departments (first-level administrative divisions) reported as places of fisheries conflict. This covers all coastal departments but two, plus four inland departments.

Claims in the conflicts were diverse and often combined a chain of interconnected problems. Along with the main matter reported, each case was often associated with issues that in turn configured other types of conflicts. We focus here on the main issue reported in each film. Thus, three major types of conflicts emerged (Table 1). The first referred to tensions within the fishing sector that caused environmental degradation (blue points in Fig. 1). The second involved the clash of fishing with another economic activity (red points). In our dataset, this type occurred in inland fisheries only. The third encompassed institutional and cultural tensions that affected the fishers (green points). We found most of the conflicts within the third type in coastal fisheries.

Across types of conflicts, the films denounced damages over a variety of elements of the biophysical environment, ranging from broad features (e.g., landscape, land, water, protected areas), to concrete ecosystems (e.g., benthos, river mouth, mangrove). The pieces also reported impacts that affect specifically the SSF sector, such as impacts on fishing grounds or certain species habitats, and the introduction of alien species that affect fishing resources, e.g., carp (Cyprinus carpio). The harvested species most frequently mentioned in the pieces were "bocachico" (Prochilodus magdalenae), "blanquillo" (Sorubim cuspicaudus), and "bagre rayado" (Pseudoplatystoma magdaleniatum) for inland water conflicts; and "robalo" (Centropomus undecimalis), "jurel" (Caranx hippos), and tuna (Thunnus spp.) for marine conflicts.

The pieces represented some level of violence across all types of conflicts. Particularly pronounced was the violence related to the degradation of ecosystem and fishing resources, which involved armed conflict and violation of human rights, and the tensions between fishing and monocultures (see Table 1). Additionally, the allegation of direct violence against fishers was a specific type of 
Table 1. Types of detected fisheries conflicts, affected ecosystems, and related issues. Source: Content of the films and questionnaires completed by film producers. Note: M (Marine), I (Inland); the dot represents occurrence. Violence is rated according the perception of the film producers on the extent to which their own piece represents violence (*** High; ${ }^{* *}$ Medium; * Low).

\begin{tabular}{|c|c|c|c|c|c|c|}
\hline Type of conflicts & & M & I & $\begin{array}{l}\text { Ecosystem / Biophysical } \\
\text { environment }\end{array}$ & Violence & Other associated conflicts \\
\hline \multirow[t]{4}{*}{$\begin{array}{l}\text { Tensions within } \\
\text { the fishing sector }\end{array}$} & $\begin{array}{l}\text { Degradation of ecosystems and } \\
\text { fishing resources }\end{array}$ & $*$ & $*$ & $\begin{array}{l}\text { Wetland, forest, mangrove, river, } \\
\text { lagoon, protected areas, fishing } \\
\text { grounds, water }\end{array}$ & $* * *$ & Armed conflict; human rights \\
\hline & Illegal or irresponsible fishing & $*$ & & $\begin{array}{l}\text { Sea/ocean, river, mangrove, } \\
\text { fishing grounds }\end{array}$ & $* *$ & $\begin{array}{l}\text { Fishing regulation; environmental } \\
\text { degradation; overfishing }\end{array}$ \\
\hline & $\begin{array}{l}\text { Fisheries' pressure on threatened } \\
\text { marine species }\end{array}$ & $*$ & & $\begin{array}{l}\text { Mangrove, coral reef, sea/ocean, } \\
\text { water }\end{array}$ & $*$ & $\begin{array}{l}\text { Ecosystem degradation; irresponsible } \\
\text { fishing; overfishing; pollution }\end{array}$ \\
\hline & Unsustainable fishing methods & $*$ & & $\begin{array}{l}\text { Swamp, bentos/benthic terrain, } \\
\text { sea/ocean, wetlands, water }\end{array}$ & $*$ & Waste management; incidental fishing \\
\hline \multirow{3}{*}{$\begin{array}{l}\text { Fishing clashes } \\
\text { with other } \\
\text { economic } \\
\text { activity }\end{array}$} & Fishing vs infrastructures & & $*$ & River & $*$ & - \\
\hline & Fishing vs monocultures & & $*$ & Forest, crops, water, landscape & $* * *$ & $\begin{array}{l}\text { Land access; illegal crops; hydro- } \\
\text { morphological alteration; pollution }\end{array}$ \\
\hline & Fishing vs mining & & $*$ & $\begin{array}{l}\text { River, mountains, forests, land, } \\
\text { water, sea/ocean, fishing grounds }\end{array}$ & $* *$ & Armed conflict; transportation \\
\hline \multirow{4}{*}{$\begin{array}{l}\text { Institutional and } \\
\text { cultural tensions } \\
\text { around fishing }\end{array}$} & $\begin{array}{l}\text { Lack of fishers' participation in } \\
\text { legal frameworks }\end{array}$ & $*$ & & Sea/ocean, fishing grounds & $* *$ & $\begin{array}{l}\text { Fishing regulation; overfishing; fishers } \\
\text { livelihood; surveillance and monitoring }\end{array}$ \\
\hline & $\begin{array}{l}\text { Loss of fishers biocultural } \\
\text { diversity and livelihoods }\end{array}$ & $*$ & $*$ & $\begin{array}{l}\text { River, wetland, swamp, bentos/ } \\
\text { benthic terrain, Sea/Ocean }\end{array}$ & $* *$ & Fisheries resources \\
\hline & Uncertain land and fishing rights & $*$ & & Open sea, sea/ocean & $* *$ & $\begin{array}{l}\text { Displacement; land/resource access; } \\
\text { megaprojects; deforestation; clashes } \\
\text { between economic activities }\end{array}$ \\
\hline & Violence against fishers & $*$ & & $\begin{array}{l}\text { Wetland, mangrove, river, river } \\
\text { mouth, forest }\end{array}$ & $* * *$ & $\begin{array}{l}\text { Coastal erosion; displacement; } \\
\text { deforestation; pollution; monocultures; } \\
\text { mining }\end{array}$ \\
\hline
\end{tabular}

institutional conflict that even encompassed the displacement of fishing communities.

Gender considerations were not at the core of the films' content. The representation of women in fishing activities tended to be moderate or low, except for a few cases, mostly in coastal areas, that emphasized women's role as fishers, traders, or promoters of fisheries conservation projects.

The films emphasized the vulnerable entities of the fisheries conflicts. In more than half of the reported cases (55\%), these were the fishers and their livelihood. All conflicts were related to institutional and cultural tensions, and at least one-fourth of the other types represented threats to fishers. In contrast, the tensions within the fishing sector tended to imperil fisheries resources and the maintenance of healthy environments. Other vulnerable entities portrayed in the films were future generations, local cultures, indigenous communities, and wetlands or, more generally, Mother Nature.

All in all, the films clearly expressed a concern for issues that affect fishers. The consideration of the fishers' views and their involvement in the film was rated between 7.4 and 8.8 out of 10 by the producers of the films across different types of conflicts. Still, the initiative of the film production was usually external to the community. The actual community engagement in film production tended to be low or moderate, with only $15 \%$ of the pieces presented reporting a very high participation of fishers and community members in all stages of the production.
Films portray fisheries conflicts as processes of change Systematizing the content of the films provides a picture of conflicts over SSF in Colombia with drivers and impacts in inland waters akin to patterns in marine and coastal environments but with diverging responses or calls for action (Fig. 2, Appendix 2). Common drivers and pressures portrayed in the films encompassed weak institutions, and the lack of a good systems for surveillance and monitoring. Notably, the armed conflict and violence was also a shared stressor. Multisector pressures, especially those linked to extraction projects of subsoil resources or biomass, seemed to affect particularly inland fisheries as well as pollution. Meanwhile coastal and marine fisheries faced colliding values within the fishing sector, which led to increasing fishing effort, overfishing, and the use of unselective fishing methods, without an effective guiding role of the government to cope with this problem.

As a result, small-scale fishers perceived multiple impacts. Both inland and marine fisheries suffered from ecosystem and habitat degradation, accompanied by an observed decline in the fishers' quality of life, with even their food security put at risk. Many fishers saw their livelihoods diminished or no longer viable. An important implication that the films emphasized was the fading away of SSF in the Colombian economy. Another shared impact was the decrease in fishing areas, the changes in species populations, and a feeling of cultural loss. Fishers in the coastal 
Fig. 2. Drivers-pressures (a), impacts on (b), and responses (c) to unwanted developments in the small-scale fisheries sector of Colombia reported in the films.

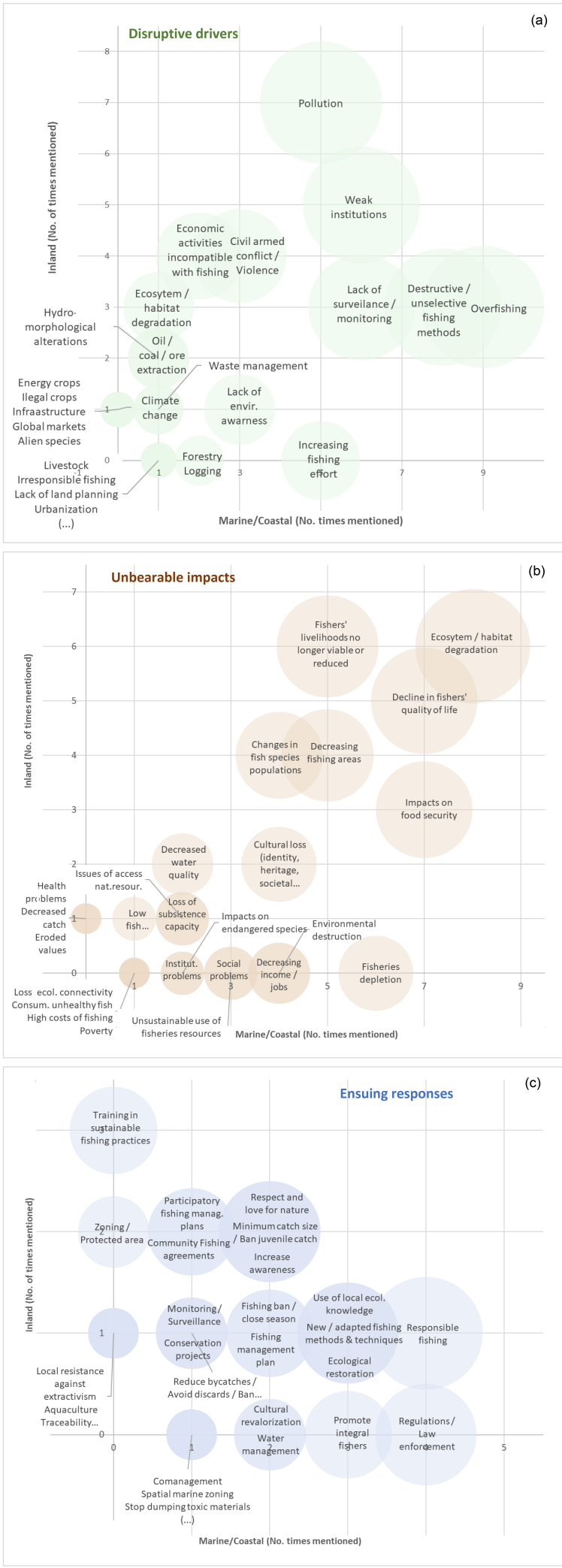

and marine fisheries perceived some effects more frequently, such as the impacts on endangered species, decreasing income and jobs, and fisheries depletion.

Responses to this situation were assorted. Political mobilization and local resistance were a small part of the responses. More frequent were the calls for tackling specific pressures with ad hoc measures. Common responses across types of fisheries included the promotion of increased environmental awareness, and enhanced respect for life and for the environment. The call for the affective realm does not mean that recommendations for technical improvement or bans to unsustainable practices, as well as enhanced monitoring and surveillance are not necessary. In the marine and coastal areas, proposals involved the creation of new regulations or the enforcement of existing laws, capacity building for fishers, and fishers' cultural revalorization. Fishers in inland SFF expressly requested training in sustainable fishing practices and zoning.

\section{Films aim to support transformation}

Purpose of the films

According to the film producers and participants of the docuconference, a key use of the films was knowledge sharing, involving the purposes of dissemination (including science dissemination), awareness raising, education, and attracting public attention on facts about the conflict. This broad category encompassed knowledge creation by systematizing or documenting experiences, e.g., of success stories of SSF management, or a baseline of evidence in underreported cases of conflict.

Also frequent was using films for persuasion and political mobilization. Starting from a claim or complaint, the users aimed at increased visibility of the conflicts, and social mobilization, empowerment, community engagement (for instance, in conservation practices), and alliance formation. Finally, films served social functioning purposes including artistic/aesthetic expression, cultural valorization, consolidation of identity and memory, promoting environmental values such as the respect for nature, and giving hope to communities under pressure. Across the different purposes, the main target of the films was the general public, followed by the local communities, and decision makers (mainly governmental institutions). Researchers were also a target audience, albeit minor.

The convergence of several purposes in every piece allowed for an analysis of co-occurrence, as well as of the links between actors and their respective goals while using the films (Fig. 3). We used modularity analysis to reveal three clusters of converging interests in the assemblage of film producers and their respective purposes. A first group united indigenous people and local communities (IPLC), academia (both researchers and students), and the media. They tended to use films to denounce the pressures and impacts suffered by the SSF, attract public attention, and make the conflicts visible. Awareness raising and education were among the most important pursuits of this group, which also emphasized cultural aspects linked to SSF management identity and memory. The second group connected conservation NGOs, fisheries authorities, and production companies that employ films for dissemination purposes. In this group, there was a strong artistic and aesthetic aspiration, and films were used to promote 
Fig. 3. Network of purposes and film producers. Note: Radial axis layout, grouping nodes by modularity class. Data on target audience, added manually. IPCL, indigenous people and local communities.

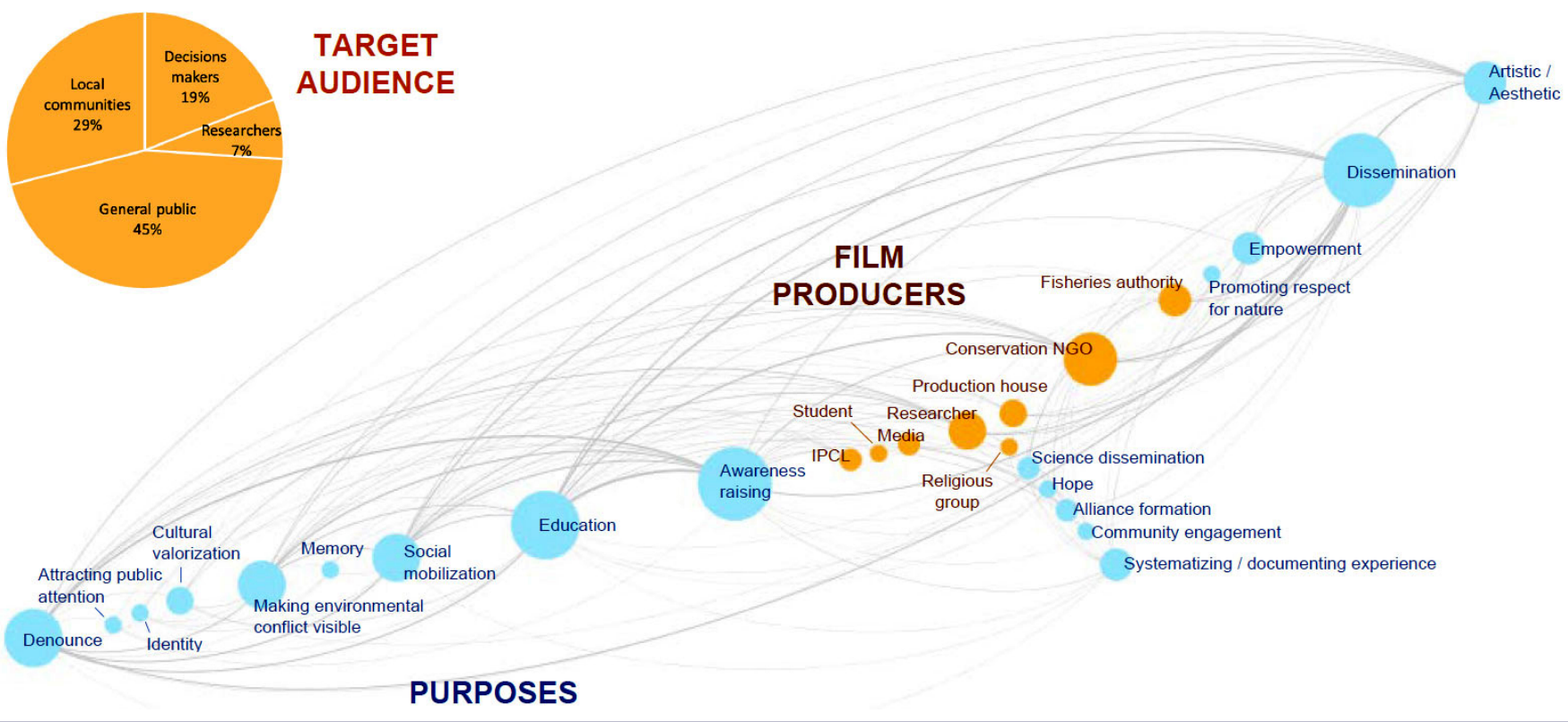

environmental values and spread the discourse of empowerment. In the third group, faith communities aimed at creating evidence by compiling facts in the films, giving hope, and engaging the community with conservation practices. Interestingly enough, the third group was the one emphasizing science dissemination the most.

\section{Perceived effects}

Not much has been said about the effectiveness of artistic practices in conflicts, or in environmental management in general. The collected materials provided evidence about the perceived results of using films, beyond the original intentions of the producers and users. The story film producers told, and participants discussed during the docu-conference, departed from the ability of films to expand knowledge and relations among people with interest or concern in fishing management. Intellectual processes of thinking and feeling followed, triggering action in two ways: through manifestations of support or disapproval, or through changed states of the issue at hand (Fig. 4).

Fig. 4. Chain effects of using films in fishing conflicts

\begin{tabular}{|c|c|c|}
\hline Films about fishing conflicts expand ... & ... thus triggering \\
\hline Visibility & ... propelling & Support \\
Evidence & $\begin{array}{c}\text { Representation } \\
\text { Expression } \\
\text { Dissemination } \\
\text { Awareness }\end{array}$ & $\begin{array}{c}\text { Emotion } \\
\text { Reflection } \\
\text { Complexity }\end{array}$ \\
\hline
\end{tabular}

Direct input from the producers plus the discussions at the time of the screening suggested that films operated as tools for the visibility of the fisheries conflicts, and of the socioeconomic implications of land management with effects on SSF. In fact, the film producers compiled a pool of evidence, systematizing relevant facts and processes in the conflicts, and creating records of both success stories and injustices witnessed by the fishing communities. In this respect, the producers thought that the films consolidated a memory of important events in the fishing communities that could be lost otherwise.

An important outcome was dissemination. Films were an excellent communication method, perceived as far more superior in terms of outreach than other channels of scientific or institutional information. Users praised the dynamism of audiovisual materials, with easy-to-remember content and high potential to spread information fast. Therefore, films can transfer ideas about success stories efficiently. A fisher leader from the Atlantico Department applauded the opportunity of "bringing this dissemination medium to organized communities ... that already have the capacity to participate in management so as to motivate other fishing communities in Colombia with their example." In remote fishing communities, films even replaced inaccessible mass media. In this respect, films helped researchers to give back to the community in easier ways than the mere delivery of reports and documents that very few would eventually read.

According to the participants of the docu-conference, films raised awareness about the conflicts along the fishing commodity chain and possible actions to face them. More generally, participants agreed that films promoted environmental awareness. They constituted a powerful educational tool that, for instance, introduced youngsters to the issues of the fishing sector. In the words of a fisher from the Santander Department: "We are using 
the films with schools. So, we can also reach the heart of those who do not want to see or accept the reality."

The production and use of the films entailed relational effects, both between people and between ideas. "Yes, the idea was disseminating information, but also bringing people together and meeting allies, creating closer ties in order to preserve the resources and make our voices heard" (Marine program officer, Environmental NGO). Film production helped to merge efforts and connect different institutions, stimulating interstakeholder conversations, collaboration, and coordination. Films also enhanced social cohesion within the communities, for instance through intergenerational links, and their use promoted encounters between previously disconnected communities. Another relational effect was the interconnection of different elements of identity portrayed in the films.

The expanded knowledge base and the increased relatedness boosted several forms of intellectual development that were relevant for understanding the conflicts and their implications. The films became a mirror where local communities saw themselves represented, giving voice to different viewpoints involved in the conflict. "The voices are from the region, everything that was done is from the region. ... We build on the grounds of what the community wanted. Films are supportive as they provide feedback on communities' own views" (Wetland conservation NGO). Beyond the mere representation of the fishers as victims, the films revealed their cultural significance and agentic capacities. Films provided an outlet for the people's need to express themselves, e.g., in the face of injustice. Likewise, films offered a channel for the creative talent of young people. All in all, the films configured a space for reflection about the current situation and prospects of the SSF.

Contributing to audio-visual content empowered communities, or groups within the community, e.g., young people or children. "The communities feel themselves empowered by generating their own films. The Communication Collective [name of the collective, in the Chocó Department] is an example. It is constituted by community members who have trained themselves and learned how to use films for showing internal processes in the community" (Advocacy organization member). A key benefit was to form emotional connections with the issues at hand. Often, the emotions were positive, and films conveyed joy and offered positive notes for the future, as members of the audience pointed out. This was praised in the contexts of stressful pressures suffered by actors in the conflict. Finally, the films had a unique integrative capacity in the context of complexity, and hence they promoted interdisciplinarity: a fisher participating in the docu-conference summarized: "a film is worth much more than a thousand words."

The above triggered two types of actions, according to the participants. The first consisted in moving the conflict from a situation of latency to a manifest stage. On the one hand, some groups (e.g., fishers, younger generations) or campaigns received support, solidarity, and social ownership of the ideas promoted. On the other hand, the actors in the conflict openly denounced unwanted situations and protested the pressures suffered. In this respect, the films exacerbated tensions and led to more dynamic discussions, controversy, and public scandal. "I believe that there are vibrant moments when [films] generate controversy. To create a buzz is already a good outcome" (Wetland conservation NGO).

The second type of action, fed by the previous one, was changing the situation through three basic avenues. First, people gained an increased level of place attachment to the lands and water bodies shown in the videos. Changes in values stemmed from a connection with "reality" and a "direct" contact with impacted communities, their livelihoods, and their plights that were in fact mediated by the content of the films. Second, the films enhanced the governance of the fishing sectors, promoting local engagement and self-management of community organizations, e.g., comanagement experiences and local consultations. These served as examples of success to other fishing communities. Third, the films promoted management toward more sustainable fishing practices, such as community-based monitoring or the proposal of new conservation areas. Another fisherman from Santander summarized: "Thanks to the film we united forces. Without governmental intervention, we organized two fishing bans in the Magdalena River, in our swamps, and in our streams. With the fishing ban, we protected the "bocachico," the "doncella," the "pacora," the "bagre," and all our species; this is a yield that we created; our resources in our precious land."

Limitations of the films and conditions for effective use Although perceived as effective at multiple levels, several limitations restricted the potential of the films to promote the desired changes:

- Practical limitations started from technical conditions because film production required skills or access to technologies, e.g., stable electric power supply and internet connection, that most communities lack. The economic cost of film production further narrowed the narrative to reduced geographic spans regardless of the actual scope of the problem at hand.

- Framing limitations emerged from the frequent absence of decision makers (governmental institutions of corporate actors) in the moment of production or screening of the films. Rather than risk of bias, which was also mentioned, the drawback was a reduced potential for constructive debates. Issues of framing also emerged from the need to contextualize the problems of the fishing sector within a broader set of relevant socio-environmental processes that are hard to compress into a short film. A recurrent topic of discussion during the screening of the films, for instance, was corruption.

- Representation limitations arise in some cases from the absence of other voices from the land aside from the fishers. Also, when film producers were external to the community, an inescapable disconnection with local values increased the risk to disseminate wrong messages or culturally unsuitable recommendations.

- Research-related limitations were mostly related with mistrust toward academia, often because of past experiences of researchers not "giving back" to the community that collaborated with them for the completion of a project.

- Institutional limitations emerged from biased receptions of the message or possible misuses of the piece, especially when 
the actors driving a stressor on SSF dominated the conversation. A critical institutional limitation was the real threat of putting local leaders at risk of violence (and even of death) once their involvement with the conflict was disseminated in the film.

Mirroring such limitations, participants identified three types of conditions for effective use of videos as a source of transformation in the conflicts. The first was framing the films in ways that prevented ambiguity and clearly conveyed the need of a collective change. The relevance of context was critical. Nothing was to be gained, said the participants, from isolating narratives of pressures on SSF from other environmental pressures, or disconnecting such narratives from the overall socioeconomic context. If the film was not explicit enough, the gap between content and context needed to be bridged with ad hoc activities during the film screening. Beyond being informative, the pieces needed to promote environmental awareness and collective action to support self-subsistence and autonomy of the fishers. A proper articulation with local identities may guarantee that the fishers see themselves identified with the offered narrative.

This led to a second condition, related with the engagement of communities and fishers in the film production. This meant involving fishers, and other key actors in the community, at all stages of the process, and giving them direct voice about the conflicts they perceive. Active involvement may require training in film production with adequate technologies, and engaging with community concerns, with a proper understanding of fishing strategies and local notions of environmental stewardship. Local production of short videos could also help to overcome technical and resource constraints for external film production, ensuring that relevant cases are followed up in different moments of the process.

An expected benefit was the portrayal of different positions and roles played by community actors, both positive and negative. According to the participants, the gained sense of realism ensured the appropriation of the materials by the actors involved (especially the fishers), which is another necessary condition for a productive discussion about environmental justice in the communities. During the projection of the films, participants featured cases as a potential focus of further films. Participants stressed the significance of bringing information about such cases to other communities to promote their mobilization. Benefits of engagement also emerged from intergenerational communication.

Third, arrangements during the production of the film reinforcing interstakeholder coordination in film production and use, involvement of professional filmmakers, and adequate dissemination are key for an effective use of the films as a source of transformation. The coordinated preparation and use of the materials should involve donors, NGOs, fishers, local managers, and authorities. Combined with other participatory artistic/ experiential activities, such as visits to the affected areas, film use promotes peer-to-peer knowledge sharing. The search for alliances between entities linked to the fishing sectors is part of this coordination. So is ensuring media coverage of the film production and screening and protecting local leaders who engage with the production.
Interdisciplinarity and fact checking is to be expected by linking the production with academic research, incorporating scientifically reliable messages from different disciplines with clear content. The engagement with science goes hand in hand with cultural valorization, preventing prescriptive messages against community traditions. The engagement of professional filmmakers seems advisable to strengthen the quality of the produced films, but this requires clarifying mechanisms for protection of intellectual property rights of content creators.

\section{DISCUSSION}

\section{Expanded knowledge about types of small-scale fisheries conflicts and their dynamics}

The introduction of this paper noted the worldwide increase of fisheries conflicts, particularly in the last four decades. While advancing knowledge, global studies on this matter (see Spijkers et al. 2019) seem to underreport fisheries conflicts in South America that nonetheless appear in the media, e.g., radio, TV, social networks, web pages (Dejusticia, https://www.dejusticia. org/; Foro Nacional Ambiental, http://www.foronacionalambiental. org.co/; Universidad Nacional de Colombia, http://oca.unal.edu. $\mathrm{co} /$ ) and are well known by directly affected local people, such as the participants in our research. By compiling audio-visual materials about conflicts from half of the 32 Colombian departments, this study contributes to the understanding of SSF conflicts that have mobilized fisheries stakeholders inside and outside the fishing communities in the country.

Colombia's ecosystemic and cultural complexity manifests itself in both continental and marine environments (Carrizosa Umaña 2014). Historically, continental ecosystems suffered stronger pressures as spaces for small-scale fisheries. In the last decades however, increased stressors affected marine environments and led also to fisheries degradation. It is not rare then that our study found shared characteristics in SSF conflicts affecting stability in marine and continental ecosystems. Still, the economic activities that trigger the conflicts differ. In marine waters port infrastructure generates significant impacts (see, e.g., SaavedraDíaz et al. 2015, Bennett et al. 2020) while in inland waters the films reflected the impact of hydroelectric plants and dams (see Jiménez-Segura et al. 2014, Da Costa Doria et al. 2018). Overall, a problem of continental SSF is the scarcity of studies about fishing resources and ecosystems in Latin-American regions (Saavedra-Díaz and Jentoft 2017, Barragán Paladines et al. 2019). Our work contributes to bringing awareness to these issues and to filling part of this knowledge gap.

Further, our study positions the issue of violence against fishers as a key constituent of SSF conflicts. Blue crimes, crimes at sea, or fishery crimes are becoming a visible issue in SSF (Bueger and Edmunds 2020, Witbooi et al. 2020). In these new studies, violence in the fisheries sector results from interactions with other activities in the same fishing territory, such as drug trafficking, illegal crops, infrastructure, and extractive industries. As a result, fishers suffer from violations of human rights, including forced labor, forced displacement, robbery, and murder of fisher leaders. Yet global studies on violence against fishers are rare (Ratner et al. 2014). For the Colombian case, most of these types of violence were present but poorly documented. Moreover, five decades of illegal 
armed conflict took its toll on fishers as well (Saavedra-Díaz and Jentoft 2017). Our results confirm different levels of violence (low, medium, or high) perceived across all types of conflicts and areas reported (Table 1). Besides direct aggressions as the ones listed above, the films depicted pervasive harmful effects (on local ecosystems, cultures, and economies) of the set of unwanted drivers over SSF, evoking the notion of slow violence, one "of delayed destruction that is dispersed across time and space, an attritional violence that is typically not viewed as violence at all" (Nixon 2011:2).

Among the three types of conflicts categorized by this research, the first type (related to tensions within the fishing sector) is comparable to the way fisheries conflicts are documented worldwide (FAO 2020; the Secure Fisheries Program web site) and in Colombia (Acero and Polanco 2017, Chasqui et al. 2017). The other two types (clashes between SSF and other economic activities, and institutional and cultural tensions that impact SSF) are less discernible in recent studies in Colombia (Mojica et al. 2012 for continental ecosystems; Saavedra-Díaz et al. 2015 for marine ecosystems), but somehow recognized in global analyses, such as the study on Blue Acceleration (Jouffray et al. 2020).

Both categories of SSF conflicts are mainly related with cooccurrence of fishing and other external activities in the same territory. In Colombia, as in other Latin-American countries, these tensions increased over the last decades (FAO and MinAgricultura 2014, OEDC 2019) as governmental priorities turn toward economic agendas framed as "Blue Economy" or "Blue Growth" (Bennett et al. 2020). Noting the vulnerability of the affected populations, especially in developing countries, global voluntary instruments and provisions (such as Code of Conduct for Responsible Fisheries, Voluntary Guidelines for Securing Sustainable Small-Scale Fisheries in the Context of Food Security and Poverty Eradication, and Sustainable Development Goals) promote a human-rights approach to tackle conflicts related to the SSF sector (FAO 2015, Singh et al. 2018). However, pervasive issues of inequity and inequality around the SSF worldwide have motivated the emergence of the "Blue Justice" movement to emphasize the concrete needs of the SSF sector within the Blue Economy agenda (Bennett et al. 2020). Meanwhile, the Colombian government keeps promoting ocean extractive activities in its attempt to position the country as a "Sustainable Bioceanic Power" for 2030 (CCO 2020), while expanding port infrastructure with negative effects over SSF (Saavedra-Díaz et al. 2020). The Colombian government has also long pushed for the construction of hydroelectric megaprojects with disruptive effects in inland SSF that eventually trigger conflicts (Rueda et al. 2011, Jiménez-Segura et al. 2014, Garcia 2016).

The range of conflicts identified in our study confirms and builds over previous research about fisheries conflicts. In line with the strong social component of filmmaking, the content of the films tends to emphasize the human and social dimensions of the conflicts. The ecological aspects are present in the narrative, but typically not at the core of the message. Yet the films convey the critical reliance of social subsistence on the integrity of the ecological and natural resources systems.

\section{Use of filmmaking in interventions on small-scale fisheries conflicts}

Films offer a powerful tool for purposes that our study helps to identify, cluster, and associate with the different actors in the conflict. Unsurprisingly, governmental actors and conservation NGOs tend to use films to disseminate institutional or proenvironmental messages. For years now, conservation ecologists have praised the capacity of visual arts to synthesize complex scientific messages (Curtis et al. 2012).

Meanwhile education and awareness raising are a major goal of fisheries communities and researchers who work with them. Simultaneously, communities use films to render more visible pressures they suffer and that otherwise would remain hidden. In line with Wiebe (2015), we learned that visual media, and films in particular, are distinctively fitted to improve antioppressive knowledge generation. Indeed, Blewitt (2011) emphasizes critical engagement with the content as a requirement for promoting conservation behaviors and transformations through education and awareness using visual media. In this respect, the docuconference we organized as an interactive data gathering process emerged as a needed space of dialogue among the different actors involved in the films, and it was praised as such by the participants. As Cumming and Norwood (2012) also note, a fruitful deliberation hinged on the hybrid nature of the films, exposing the viewers both to facts and to intimate reflections of the involved parties.

The use of films to support scientific research about SSF was a main motivation of this paper. Parts of the discussion above show that compiling films and discussing them with communities and other involved actors provided data about SSF rapidly and far beyond existing academic reports. In the decades-long experience of two of the authors, achieving similar first-hand data about environmental conflicts, their location, actors involved, types of conflicts, and their perceived causes, impacts, and possible courses of action would take long and costly fieldwork activities. Thus, films are a valuable source of information that allow making visible issues previously unnoticed by academic researchers.

Beyond being a source of factual data, films offer understandings of intra-community dynamics in ways that conventional scientific analysis would hardly capture. In this respect, our investigation tests the potential of film-related research activities as a methodological tool to interact with communities in a more horizontal and creative manner than surveys, interviews, focus groups, and other forms of qualitative research. This entails a change in the discourse and practice of (social-)ecological sciences that is open to arts-based analysis, similar to what has already occurred in other domains of natural-resource management (Fernández-Giménez 2015). Along with its virtues, the use of films entails challenges as a tool for knowledge development. Opening the door to new constituents of the ecosystem-related topics, e.g., perceptual, procedural, and emotional, does not preclude fact-checking against available scientific expertise (see, e.g., Calvet-Mir et al. 2012). Thus, ensuring scientific reliability of the content is a role that researchers can, may, and should adopt in the use of films to articulate transformations around SSF conflicts.

In agreement with Gouyon (2016), our results therefore emphasize the relevance of process over outcome in films that 
aim at engaging with policy action from scientific evidence. The research participants (filmmakers, fishers, and the public in the event) discussed advantages and weaknesses that the SSF sector could face in their endeavor to use film materials as a tool to deal with the environmental crisis in Colombia. Such conversation disclosed specific parts of the process that contribute to more effective usage, its conditions, and limitations.

A clear insight was that collaborative film production tends to underpin the transformative potential of the films, as also highlighted by Wiebe (2015). Although the whole film production offers opportunities for community participation, our investigation pinpoints two critical moments of such collaboration: the framing the film project, and the time when the film is screened and discussed.

In this respect, SSF conservation is not delinked from a set of social processes that configure different frames of understanding (Bavinck et al. 2018, Scholtens and Bavinck 2018). Filmmaking helped to bridge this communication by appealing to different rationalities, e.g., of the fishes, of the researchers, and of the governmental officers, and ensuing forms of representation, and the expression of emotions. The representation of marine environments, and aquatic ecosystems in general, have been influenced by high-quality film production and notions of paradise or wilderness (Kennerson 2008). For instance, when the theme of the World Exhibition held in Lisbon in 1998 was "The Oceans, a Heritage for the Future," the aesthetics of the exhibitions created a fiction of the ocean as a space of beauty and harmony that was far from the real pressures suffered the fishers. A possible outcome is that visual media may have perpetuated distorted views on the separation between humans and the environment (Blewitt 2011).

The reality we unveiled is different. The use of more modest production, often through short formats such as clips or selfproduced short videos, fits the real needs of the fishers in SSF conflicts. When communities appropriate the production process, an opportunity emerges to present facts under a different light. "Creating visibility can mean disseminating images that are not spectacular, but rather images that illustrate ... everyday life, the daily struggle, but also the will to survive, or indeed even the beautiful and poetic moments of reality otherwise marked by hardship" (Heissenbüttel 2014: 475).

This point got reinforced when the authors were preparing the present discussion during the period of restrictions imposed by the COVID-19 pandemics. The precarious lifestyle of the smallscale fishers was once again hit by external conditions that further limited their access to resources and markets (EFE 2020). Then, as a survival strategy, fishers resorted to producing short videos to voice their situation in a timely manner and advertise their products to distant consumers who could support them.

The visuals thus produced may not appeal to a conventional artistic experience, but they provide a glance to the lifestyle of actors in the field, their actual concerns, and the processes that shape such concerns and their very identities. For the researchers interested in SSF conflicts, audio-visual materials offer an understanding of the conflicts as processes, rather than as isolated events of social mobilization. The webs of relations (Rocheleau 2008) that are thus unveiled bring both the stakeholders and their audiences through a process that connects the perception of complex facts, affect (via emotions, expression, and reflection), and behavioral change, as shown in Figure 4. This confirms previous insights from literature linking the arts with the communication of ecological knowledge (Curtis et al. 2012), as well as the setting of a reflective tone in deliberations about land use planning (Cumming and Norwood 2012). Therefore, we contribute to previous attempts to clarify the role of emotions in struggles for socio-environmental transformation (Gonzalez Hidalgo 2017), with the specific scope of engaged filmmaking.

\section{CONCLUSIONS}

In this paper we reveal the significance of visual media, and especially films, to document environmental conflicts over SSF and to promote transformations in support of vulnerable groups, such as fishers and their communities. A national call for audiovisual materials, the organization of a "docu-conference" where stakeholders exchanged viewpoints about the conflicts, and the systematic examination of the data thus compiled led to a finegrained understanding of SSF conflicts in Colombia. Our study compiled just a selection of a broader set of existing materials. Admittedly, a larger sample would provide nuance and may help to qualify the intensity of some of the processes identified above. However, we are confident that a larger sample would not challenge our key findings.

The investigation offers novel knowledge about the distribution of SSF conflicts, and their drivers, impacts, and ensuing responses. In a context of long-lasting civil unrest that hinders fieldwork research, the study was able to provide greater insights into the types of conflicts in SSF, including SSF in inland waters that hitherto had been scantly documented. Films not only make the conflicts visible, but also facilitate the appreciation of their contexts and dynamics. Films show fishers interacting within such contexts and with each other. Thus, beyond the descriptive variables compiled, audio-visual content provides different, often richer, insight into social-ecological processes and community problems than the usual interaction in the field. In the films, fishers express views about their own conditions to extents that surprised expert scientists on the topic of SSF management. At the same time, the films allow for different perspectives to be presented together, enabling a nuanced understanding of the problem at hand.

Overall, most of the films we analyzed were produced by actors external to the community with community support. Films are useful instruments, both as ways for communities to raise their voice and for outsiders to share a message or convey communities' standpoints. Besides denouncing socio-environmental problems, films voiced alternatives or solutions to those problems defended by the communities, including their views on conservation and sustainable use of fishing resources. Likewise, both governmental and nongovernmental organizations engaged in ecosystem management used films to disseminate institutional initiatives for conservation.

Compiling information from documentary films on SSF conflicts has proved to be an effective way to underpin scientific knowledge that would hardly be attained otherwise. Over time, researchers increasingly use creative means (theatre plays, songs, creative workshops, drawing contests, or photography contests) to transfer their findings or key messages to the local communities. 
Our research confirms the usefulness of this approach to the subject matter of SSF conflicts, and possibly for other types of socio-environmental conflicts as well. Beyond that, filmmaking contributes to the promotion of interdisciplinary knowledge, underpinning both access to data and the understanding of dynamic and complex socio-environmental processes within the conflicts. Hopefully, the study can stimulate more researchers to tap into the increasing availability of audio-visual materials for the study of social-ecological issues. The users of films as source materials should be aware of the multiple purposes of engaged filmmaking and how this affects the contents to be analyzed.

Of course, the resort to audio-visual media, both as a source of data or as a methodological approach, does not replace the need to connect directly with processes in the field. However, our investigation reveals a significant potential for the use of films in engaged research about socio-environmental conflicts. In this respect, some interesting lines for future research include the compilation of audio-visual media about fisheries conflicts in a broader geographic scope, both in Colombia and around the world, and the analysis of the available materials through the lens of claims from the fishers, such as human-rights vulnerabilities in the SSF sector, gender considerations, or the exiting dimensions of environmental (in)justice in the conflicts and how to redress them.

Responses to this article can be read online at: https://www.ecologyandsociety.org/issues/responses. $\mathrm{php} / 12217$

\section{Acknowledgments:}

We thank the participants and organizing team of the Docuconference AJA 2018, specially the research group "Sistemas Socioecológicos para el Bienestar Humano" and the "Vicerrectoria de Extensión y Proyección Social" at the Universidad del Magdalena. We thank the members of the Water Group+ of the Energy and Resources Group at the University of California, Berkeley, for insightful comments to a previous version of this paper. The research received funding from the Solidarity Fund of the Autonomous University of Barcelona (FAS-UAB) under the project AJA. BRL acknowledges funding from the European Union's Horizon 2020 research and innovation programme under the Marie Sklodowska-Curie Grant Agreement $N^{\circ} 797444$ (CLAMOR).

\section{Data Availability:}

The datalcode that support the findings of this study are available on request from the corresponding author, [BRL]. The datalcode are not publicly available because they contain information that could compromise the privacy of research participants. The research counts on approval for human subjects research by the Research Ethics Commitee of the Universidad del Magdalena, Colombia.

\section{LITERATURE CITED}

Acero P., A., and A. Polanco F. 2017. Biodiversidad íctica de los mares colombianos: riqueza amenazada. Revista de la Academia
Colombiana de Ciencias Exactas, Físicas y Naturales 41 (159):200-212. https://doi.org/10.18257/raccefyn.480

Andrade, C. M. G. 2011. Estado del conocimiento de la biodiversidad en Colombia y sus amenazas. Consideraciones para fortalecer la interacción ciencia-política. Revista de la Academia Colombiana de Ciencias Exactas, Físicas y Naturales 35 (137):491-507.

Arboleda, M., and D. Banoub. 2018. Market monstrosity in industrial fishing: capital as subject and the urbanization of nature. Social and Cultural Geography 19(1):120-138. https://doi. org/10.1080/14649365.2016.1266025

Arthur, R., R. Friend, and C. Béné. 2015. Social benefits from inland fisheries: implications for a people-centred response to management and governance challenges. Freshwater Fisheries Ecology. https://doi.org/10.1002/9781118394380.ch39

Autoridad Nacional de Acuicultura y Pesca (AUNAP) and Unimagdalena. 2014. Caracterización de los principales artes de pesca de Colombia y reporte del consolidado del tipo y número de artes, embarcaciones y UEP's empleadas por los pescadores vinculados a la actividad pesquera. AUNAP and Unimagdalena, Bogotá, Colombia.

Barragán Paladines, M. J., S. Salas, L. M. Saavedra-Díaz, N. Gaibor, M. J. Espinosa, M. Arce Ibarra, and R. Chuenpagdee. 2019. Strengthening collaborations on small-scale fisheries research in Latin America and the Caribbean. Too Big To Ignore Research Report, number R-02/2019, St. John's, Newfoundland, Canada.

Bastian, M., S. Heymann, and M. Jacomy. 2009. Gephi: an open source software for exploring and manipulating networks. International. AAAI Conference on Weblogs and Social Media. Association for the Advancement of Artificial Intelligence, Palo Alto, California, USA.

Bavinck, M., S. Jentoft, and J. Scholtens. 2018. Fisheries as social struggle: a reinvigorated social science research agenda. Marine Policy 94:46-52. https://doi.org/10.1016/j.marpol.2018.04.026

Bennett, N., J. Blythe, C. White, and C. Campero. 2020. Blue growth and blue justice. IOF Working Paper \#2020 - 02. Institute for the Oceans and Fisheries, University of British Columbia, Vancouver, British Columbia, Canada.

Blewitt, J. 2011. The media, animal conservation and environmental education. Environmental Education Research 17 (6):711-718. https://doi.org/10.1080/13504622.2011.625624

Blondel, V. D., J.-L. Guillaume, R. Lambiotte, and E. Lefebvre. 2008. Fast unfolding of communities in large networks. Journal of Statistical Mechanics: Theory and Experiment P10008. https:// doi.org/10.1088/1742-5468/2008/10/P10008

Bueger, C., and T. Edmunds. 2020. Blue crime: conceptualising transnational organised crime at sea. Marine Policy 119:104067. https://doi.org/10.1016/j.marpol.2020.104067

Calvet-Mir, L., E. Gómez-Baggethun, and V. Reyes-García. 2012. Beyond food production: ecosystem services provided by home gardens. A case study in Vall Fosca, Catalan Pyrenees, Northeastern Spain. Ecological Economics 74:153-160. https:// doi.org/10.1016/j.ecolecon.2011.12.011 
Carrizosa Umaña, J. 2014. Colombia Compleja. Jardín Botánico de Bogotá José Celestino Mutis. Instituto de Investigación de Recursos Biológicos Alexander von Humboldth, Bogotá, Colombia.

Chasqui, L., A. Polanco F., A. Acero P., P. A. Mejia-Falla, A. Navia, L. Zapata, and J. P. Caldas. 2017. Libro rojo peces marinos de Colombia. Instituto de Investigaciones Marinas y Costeras Invemar, Ministerio de Ambiente y Desarrollo Sostenible, Santa Marta, Columbia.

Chouhan, H. A., D. Parthasarathy, and S. Pattanaik. 2017. Urban development, environmental vulnerability and CRZ violations in India: impacts on fishing communities and sustainability implications in Mumbai coast. Environment, Development and Sustainability 19(3):971-985. https://doi.org/10.1007/s10668-016-9779-6

Clover, D. E. 2011. You've got the power: documentary film as a tool of environmental adult education. Journal of Adult and Continuing Education 17(2):20-35. https://doi.org/10.7227/ jace.17.2.4

Comisión Colombiana del Océano (CCO). 2020. CONPES Colombia Potencia Bioceánica Sostenible 2020. CCO, Bogotá, Colombia. [online] URL: http://www.cco.gov.co/cco/publicaciones/83publicaciones/794-conpes-colombia-potencia-bioceanica-sostenible. $\underline{\mathrm{html}}$

Coulthard, S., D. Johnson, and J. A. McGregor. 2011. Poverty, sustainability and human wellbeing: a social wellbeing approach to the global fisheries crisis. Global Environmental Change 21 (2):453-463. https://doi.org/10.1016/j.gloenvcha.2011.01.003

Cumming, G., and C. Norwood. 2012. The community voice method: using participatory research and filmmaking to foster dialog about changing landscapes. Landscape and Urban Planning 105(4):434-444. https://doi.org/10.1016/j.landurbplan.2012.01.018

Curtis, D. J., N. Reid, and G. Ballard. 2012. Communicating ecology through art: what scientits think. Ecology and Society 17 (2):3. https://doi.org/10.5751/ES-04670-170203

Da Costa Doria, C., S. Athayde, E. E. Marques, M. A. L. Lima, J. Dutka-Gianelli, M. L. Ruffino, D. Kaplan, C. E. C. Freitas, and V. N. Isaac. 2018. The invisibility of fisheries in the process of hydropower development across the Amazon. Ambio 47 (4):453-465. https://doi.org/10.1007/s13280-017-0994-7

De la Hoz, J., L. Manjarres Martínez, F. Cuello, and L. Nieto. 2015. Estadísticas de captura y esfuerzo de las pesquerías artesanales e industriales de Colombia en los sitios y puertos monitoreados por el SEPEC durante el año 2015. Autoridad Nacional de Acuicultura y Pesca, Bogotá, Colombia.

EFE. 2020. Pescadores del Caribe colombiano temen morir primero de hambre que de COVID-19 [Fishers from the Colombian Caribbean are more afraid of hunger than of COVID-19]. EFE, Madrid, Spain. [online] URL: https://www.efe. com/efe/america/sociedad/pescadores-del-caribe-colombiano-temenmorir-primero-de-hambre-que-covid-19/20000013-4251365

Esquivel, M. A., M. C. Merino, J. J. Restrepo, A. Narváez, C. Polo, J. Plata, and V. Puentes. 2014. La pesca y acuicultura en Colombia. Autoridad Nacional de Acuicultura y Pesca, Bogotá, Colombia.
Fernández-Giménez, M. E. 2015. "A shepherd has to invent": poetic analysis of social-ecological change in the cultural landscape of the central Spanish Pyrenees. Ecology and Society 20(4):29. https://doi.org/10.5751/es-08054-200429

Food and Agriculture Organization (FAO). 2009. Report of the FAO/UNEP expert meeting on impacts of destructive fishing practices, unsustainable fishing, and illegal, unreported and unregulated (IUU) fishing on marine biodiversity and habitats. FAO, Rome, Italy.

Food and Agriculture Organization (FAO). 2015. Voluntary guidelines for securing sustainable small-scale fisheries in the context of food security and poverty eradication. FAO, San Salvador, El Salvador.

Food and Agriculture Organization (FAO). 2020. The state of world fisheries and aquaculture 2020. Sustainability in action. FAO, Rome, Italy.

Food and Agriculture Organization (FAO) and MinAgricultura. 2014. Política integral para el desarrollo de la pesca sostenible en Colombia. MinAgricultura, Bogotá, Colombia.

Franz, N. 2018. Exploring Sustainable Development Goals 14.b and its proposed indicator 14.b.1. FAO Fisheries and Aquaculture Proceedings ( $F A O$ ) no. 59. Food and Agriculture Organization, Rome, Italy.

Garcia, R. 2016. Grandes, Toma de decisiones por De, organizaciones en condiciones Las, Incertidumbre: Estudio de Colombia, grandes hidroeléctricas en 2010-2020 No Title. Universidad Nacional de Colombia, Bogotá, Colombia.

Gonzalez Hidalgo, M. 2017. Emotional political ecologies. The role of emotions in the politics of environmental conflicts: two case studies in Chile and Mexico. Dissertation. Universitat Autònoma de Barcelona, Barcelona, Spain. [online] URL: https://www.tdx. cat/handle/10803/457867

Gouyon, J.-B. 2016. Science and film-making. Public Understanding of Science 25(1):17-30. https://doi. org/10.1177/0963662515593841

Guha, R., and J. Martinez-Alier. 1997. Varieties of environmentalism. Essays North and South. Routledge, London, UK. https://doi.org/10.4324/9781315070766

Gunn, W. D., and P. Horvath. 1987. The effects of an anti-nuclear war film on attitudes toward nuclear issues. Journal of Psychology 121(6):615-622. https://doi.org/10.1080/00223980.1987.9712691

Heissenbüttel, D. 2014. Protests everywhere? Pages 462-482 in P. Weibel, editor. Global activism. Art and conflict in the 21 st Century. ZKM Centre for Art and Media, Karlsruhe, Germany, The MIT Press, Cambridge, Massachusetts, USA.

Islam, M. S., and M. Tanaka. 2004. Impacts of pollution on coastal and marine ecosystems including coastal and marine fisheries and approach for management: a review and synthesis. Marine Pollution Bulletin 48(7-8):624-649. https://doi.org/10.1016/ j.marpolbul.2003.12.004

Jiménez-Segura, L. F., D. Restrepo-Santamaría, S. López-Casas, J. Delgado, M. Valderrama, J. Álvarez, and D. Gómez. 2014. Ictiofauna y desarrollo del sector hidroeléctrico en la cuenca del río Magdalena-Cauca, Colombia. Biota Colombiana 15(2). 
Jouffray, J.-B., R. Blasiak, A. V. Norström, H. Österblom, and M. Nyström. 2020. The blue acceleration: the trajectory of human expansion into the ocean. One Earth 2(1):43-54. https://doi. org/10.1016/j.oneear.2019.12.016

Kelleher, K., L. Westlund, E. Hoshino, D. Mills, R. Willmann, G. de Graaf, and R. Brummett. 2012. Hidden harvest: the global contribution of capture fisheries. Report No. 66469. WorldBank, WorldFish, Washington, D.C., USA.

Kennerson, E. D. 2008. Ocean pictures: the construction of the ocean on film. Thesis. Montana State University, Bozeman, Montana, USA.

Lima, E. G., A. Begossi, G. Hallwass, and R. A. M. Silvano. 2016. Fishers' knowledge indicates short-term temporal changes in the amount and composition of catches in the southwestern Atlantic. Marine Policy 71:111-120. https://doi.org/10.1016/j.marpol.2016.05.008

Mateo-Sagasta, J., S. M. Zadeh, H. Turral, and J. Burke. 2017. Water pollution from agriculture: a global review. Executive summary. Food and Agriculture Organization, Rome, Italy, International Water Management Institute, Colombo, Sri Lanka.

Matera, J. 2016. Livelihood diversification and institutional (dis-) trust: artisanal fishing communities under resource management programs in Providencia and Santa Catalina, Colombia. Marine Policy 67:22-29. https://doi.org/10.1016/j.marpol.2016.01.021

Mojica, J. I., J. S. Usma Oviedo, R. Alvarez-León, and C. A. Lasso, editors. 2012. Libro rojo de peces dulceacuícolas de Colombia. Instituto de Investigación de Recursos Biológicos Alexander von Humboldt, Instituto de Ciencias Naturales de la Universidad Nacional de Colombia, WWF Colombia y Universidad de Manizales, Bogotá, Colombia.

Newman, M. E. J. 2006. Modularity and community structure in networks. Proceedings of the National Academy of Sciences 103 (23):8577-8582. https://doi.org/10.1073/pnas.0601602103

Nixon, R. 2011. Slow violence and the environmentalism of the poor. Harvard University Press, Cambridge, Massachusetts, USA. https://doi.org/10.4159/harvard.9780674061194

Organisation for Economic Co-operation and Development (OEDC). 2019. Fisheries and aquaculture in Colombia. OEDC, Paris, France.

Ozduzen, O. 2018. Cinema-going during the Gezi protests: claiming the right to the Emek movie theatre and Gezi Park. Social \& Cultural Geography 19(8):1028-1052. https://doi. org/10.1080/14649365.2017.1330964

Pan, S., and C. Ryan. 2013. Film-induced heritage site conservation: the case of echoes of the rainbow. Journal of Hospitality \& Tourism Research 37(1):125-150. https://doi. org/10.1177/1096348011425497

Pauly, D., V. Christensen, S. Guénette, T. J. Pitcher, U. R. Sumaila, C. J. Walters, R. Watson, and D. Zeller. 2002. Towards sustainability in world fisheries. Nature 418(6898):689-695. https://doi.org/10.1038/nature01017

Peters, H. P. 2013. Gap between science and media revisited: scientists as public communicators. Proceedings of the National
Academy of Sciences 110(Suppl3):14102-14109. https://doi. org/10.1073/pnas.1212745110

Pfaff, M. C., R. C. Logston, S. J. P. N. Raemaekers, J. C. Hermes, L. K. Blamey, H. C. Cawthra, D. R. Colenbrander, R. J. M. Crawford, E. Day, N. de Plessis, et al. 2019. A synthesis of three decades of socio-ecological change in False Bay, South Africa: setting the scene for multidisciplinary research and management. Elementa: Science of the Anthropocene 7:32. https://doi. org/10.1525/elementa.367

Pitcher, T., D. Kalikoski, and G. Pramod. 2006. Evaluations of compliance with the FAO (UN) Code of Conduct for Responsible Fisheries. Fisheries Centre Research Reports 14:2.

Pitcher, T., D. Kalikoski, G. Pramod, and K. Short. 2009. Not honouring the code. Nature 457(7230):658-659. https://doi. org/10.1038/457658a

Pomeroy, R., J. Parks, R. Pollnac, T. Campson, E. Genio, C. Marlessy, E. Holle, M. Pido, A. Nissapa, S. Boromthanarat, and N. T. Hue. 2007. Fish wars: conflict and collaboration in fisheries management in Southeast Asia. Marine Policy 31(6):645-656. https://doi.org/10.1016/j.marpol.2007.03.012

Ratner, B. D., B. Åsgård, and E. H. Allison. 2014. Fishing for justice: human rights, development, and fisheries sector reform. Global Environmental Change 27:120-130. https://doi.org/10.1016/ j.gloenvcha.2014.05.006

Rocheleau, D. E. 2008. Political ecology in the key of policy: from chains of explanation to webs of relation. Geoforum 39 (2):716-727. https://doi.org/10.1016/j.geoforum.2007.02.005

Rueda, M., J. Gómez, L. M. Londoño, E. Viloria, D. Mármol, D. Bustos, L. García, A. Girón, J. Viaña, A. Rodríguez, C. Puentes, E. Acosta, and M. Vargas. 2011. Causas y tensores del cambio en los ecosistemas marinos y costeros y sus servicios ecosistémicos: indicadores de presión. Pages 81-125 INVEMAR. Informe del estado de los ambientes y recursos marinos y costeros en Colombia: Año 2011. Serie de Publicaciones Periódicas No. 8. Instituto de Investigaciones Marinas y Costeras "José Benito Vives de Andréis," Santa Marta, Colombia.

Saavedra-Díaz, L. M., I. Figueroa, G. P. Cordero Díaz, P. Satizábal, W. A. Leyva Tafur, and G. Noriega Narváez. 2020. The sea-side of coal mining: resisting coal ports in the Caribbean coast of Colombia. Pages 1-3 in V. Kerezi, D. K. Pietruszka, and R. Chuenpagdee, editors. Blue justice for small-scale fisheries: a global scan. Too Big To Ignore Global Publication Series, St. John's, Newfoudnland, Canada.

Saavedra-Díaz, L. M., and S. Jentoft. 2017. The role of the smallscale fisheries guidelines in reclaiming human rights for smallscale fishing people in Colombia. Pages 573-594 in S. Jentoft, R. Chuenpagdee, and M. J. Barragán-Paladines, and N. Franz, editors. The small-scale fisheries guidelines: global implementation. Springer International, Cham, Switzerland. https://doi. org/10.1007/978-3-319-55074-9 27

Saavedra-Díaz, L. M., A. A. Rosenberg, and B. Martín-López. 2015. Social perceptions of Colombian small-scale marine fisheries conflicts: insights for management. Marine Policy 56:61-70. https://doi.org/10.1016/j.marpol.2014.11.026 
Salas, S., M. J. Barragán-Paladines, and R. Chuenpagdee, editors. 2018. Viability and sustainability of small-scale fisheries in Latin America and the Caribbean. MARE Publication Series 19. Springer International, Cham, Switzerland. https://doi. org/10.1007/978-3-319-76078-0

Salas, S., R. Chuenpagdee, J. C. Seijo, and A. Charles. 2007. Challenges in the assessment and management of small-scale fisheries in Latin America and the Caribbean. Fisheries Research 87(1):5-16. https://doi.org/10.1016/j.fishres.2007.06.015

Scholtens, J., and M. Bavinck. 2018. Transforming conflicts from the bottom-up? Reflections on civil society efforts to empower marginalized fishers in postwar Sri Lanka. Ecology and Society 23(3):31. https://doi.org/10.5751/ES-10216-230331

Singh, G. G., A. M. Cisneros-Montemayor, W. Swartz, W. Cheung, J. A. Guy, T.-A. Kenny, C. J. McOwen, R. Asch, J. L. Geffert, C. C. C. Wabnitz, R. Sumaila, Q. Hanich, and Y. Ota. 2018. A rapid assessment of co-benefits and trade-offs among Sustainable Development Goals. Marine Policy 93:223-231. https://doi.org/10.1016/j.marpol.2017.05.030

Song, A. M., and A. Soliman. 2019. Situating human rights in the context of fishing rights-contributions and contradictions. Marine Policy 103:19-26. https://doi.org/10.1016/j.marpol.2019.02.017

Sowman, M. 2011. New perspectives in small-scale fisheries management: challenges and prospects for implementation in South Africa. African Journal of Marine Science 33(2):297-311. https://doi.org/10.2989/1814232X.2011.602875

Spijkers, J., T. H. Morrison, R. Blasiak, G. S. Cumming, M. Osborne, J. Watson, and H. Österblom. 2018. Marine fisheries and future ocean conflict. Fish and Fisheries 19(5):798-806. https://doi.org/10.1111/faf.12291

Spijkers, J., G. Singh, R. Blasiak, T. H. Morrison, P. Le Billon, and H. Österblom. 2019. Global patterns of fisheries conflict: forty years of data. Global Environmental Change 57:101921. https://doi.org/10.1016/j.gloenvcha.2019.05.005

Sterling, E. J., E. Betley, A. Sigouin, A. Gomez, A. Toomey, G. Cullman, C. Malone, A. Pekor, F. Arengo, M. Blair, et al. 2017. Assessing the evidence for stakeholder engagement in biodiversity conservation. Biological Conservation 209:159-171. https://doi. org/10.1016/j.biocon.2017.02.008

Stuart-Smith, R. D., A. E. Bates, J. S. Lefcheck, J. E. Duffy, S. C. Baker, R. J. Thomson, J. F. Stuart-Smith, N. A. Hill, S. J. Kininmonth, L. Airoldi, M. A. Becerro, S. J. Campbell, T. P. Dawson, S. A. Navarrete, G. A. Soler, E. M. A. Strain, T. J. Willis, and G. J. Edgar. 2013. Integrating abundance and functional traits reveals new global hotspots of fish diversity. Nature 501 (7468):539-542. https://doi.org/10.1038/nature12529

Vasudevan, P., and W. A. Kearney. 2016. Remembering Kearneytown: race, place and collective memory in collaborative filmmaking. Area 48(4):455-462. https://doi.org/10.1111/area.12238

Velez, M. A., and M. C. Lopez. 2013. Rules compliance and age: experimental evidence with fishers from the Amazon River. Ecology and Society 18(3):10. https://doi.org/10.5751/ES-05721-180310
Vikas, M., and G. S. Dwarakish. 2015. Coastal pollution: a review. Aquatic Procedia 4:381-388. https://doi.org/10.1016/j.aqpro.2015.02.051

Wiebe, S. M. 2015. Decolonizing engagement? Creating a sense of community through collaborative filmmaking. Studies in Social Justice 9(2):244-257. https://doi.org/10.26522/ssj.v9i2.1141

Witbooi, E., K.-D. Ali, M. A. Santosa, G. Hurley, Y. Husein, S. Maharaj, I. Okafor-Yarwood, I. A. Quiroz, and O. Salas. 2020. Organized crime in the fisheries sector threatens a sustainable ocean economy. Nature 588:48-46. https://doi.org/10.1038/ s41586-020-2913-5 
Supplementary material 1.

Complete list of films. Source: Own elaboration

\begin{tabular}{|c|c|c|c|c|c|c|}
\hline Title & $\begin{array}{l}\text { Production } \\
\text { year }\end{array}$ & $\begin{array}{l}\text { Supporting organization / } \\
\text { institution }\end{array}$ & $\begin{array}{c}\text { Location } \\
\text { (Department) }\end{array}$ & Type of film & $\begin{array}{l}\text { Type of } \\
\text { fishery }\end{array}$ & URL \\
\hline $\begin{array}{l}\text { Pescadores del Magdalena } \\
\text { (Fishers of the Magdalena River) }\end{array}$ & 2016 & $\begin{array}{l}\text { Cromatophoro corporation } \\
\text { Alma Foundation } \\
\text { Colombian Institute of } \\
\text { Anthropology and History }\end{array}$ & $\begin{array}{l}\text { Antioquia } \\
\text { Bolívar } \\
\text { Boyacá } \\
\text { Cesar } \\
\text { Santander }\end{array}$ & Documentary & Inland & $\begin{array}{l}\text { https://vimeo.com/179 } \\
604292\end{array}$ \\
\hline $\begin{array}{l}\text { Ciénaga Grande } \\
\text { (Ciénaga Grande, the big lagoon) }\end{array}$ & 2004-2005 & $\begin{array}{l}\text { Local community Ciénaga Grande } \\
\text { de Santa Marta }\end{array}$ & Magdalena & Music video & $\begin{array}{l}\text { Coastal- } \\
\text { Marine }\end{array}$ & n.a. \\
\hline $\begin{array}{l}\text { Mi compromise } \\
\text { (My commitment) }\end{array}$ & 2016 & $\begin{array}{l}\text { Ministry of Environment and } \\
\text { sustainable development } \\
\text { World Wildlife Foundation } \\
\text { Colombia } \\
\text { Mano amiga collective }\end{array}$ & $\begin{array}{l}\text { Guajira } \\
\text { Nariño } \\
\text { Archipiélago de San } \\
\text { Andrés y } \\
\text { Providencia }\end{array}$ & Music video & $\begin{array}{l}\text { Coastal- } \\
\text { Marine }\end{array}$ & $\begin{array}{l}\text { https://www.youtube.c } \\
\text { om/watch?v=WC9NkX } \\
\text { 2P2ts }\end{array}$ \\
\hline $\begin{array}{l}\text { Y siguen llegando por el Oro } \\
\text { (And they keep coming for the gold) }\end{array}$ & 2012 & $\begin{array}{l}\text { Asociación de Cabildos Indígenas } \\
\text { del Norte del Cauca } \\
\text { Tejido de comunicación }\end{array}$ & Cauca & Short film & Inland & $\begin{array}{l}\text { https://www.youtube.c } \\
\text { om/watch?v=UiDF4q5i } \\
\text { j30 (trailer) }\end{array}$ \\
\hline $\begin{array}{l}\text { El carbón en Colombia ¿quién gana, quién pierde? } \\
\text { (Coal in Colombia: Who wins and who loses?) }\end{array}$ & 2015 & $\begin{array}{l}\text { Center for Social Justice Studies - } \\
\text { Tierra Digna } \\
\text { Chasqui Foundation }\end{array}$ & $\begin{array}{l}\text { Cesar } \\
\text { Magdalena }\end{array}$ & Documentary & $\begin{array}{l}\text { Coastal- } \\
\text { Marine }\end{array}$ & $\begin{array}{l}\text { https://www.youtube.c } \\
\text { om/watch?v=O1LJRT } \\
\text { OUlqA\&t=458s }\end{array}$ \\
\hline $\begin{array}{l}\text { Pesca y Contaminación } \\
\text { (Fishing and Pollution) }\end{array}$ & 2017 & University of Magdalena & Magdalena & $\begin{array}{l}\text { Photography + } \\
\text { music }\end{array}$ & $\begin{array}{l}\text { Coastal- } \\
\text { Marine }\end{array}$ & n.a. \\
\hline $\begin{array}{l}\text { Ruta por el agua - Tibú/Catatumbo } \\
\text { (Route through water- Tibú / Catatumbo) }\end{array}$ & 2016 & $\begin{array}{l}\text { Grupo Semillas corporation } \\
\text { Pastoral social Diócesis de Tibú } \\
\text { HEKS EPER } \\
\text { MISEREOR IHJ HILFSWERK }\end{array}$ & Norte de Santander & Documentary & Inland & $\begin{array}{l}\text { https://www.youtube.c } \\
\text { om/watch?v=FQW3FI } \\
\text { 8gIMU }\end{array}$ \\
\hline $\begin{array}{l}\text { Guardianes y Guardianas del Oro del Magdalena } \\
\text { (Guardians of the Magdalena River's gold) }\end{array}$ & 2017 & Ichthyology and Culture Project & Santander & $\begin{array}{l}\text { Transmedia } \\
\text { (photo, video, }\end{array}$ & Inland & $\begin{array}{l}\text { http://micoom88.wixsit } \\
\text { e.com/ictiologiaycultur }\end{array}$ \\
\hline
\end{tabular}




\begin{tabular}{|c|c|c|c|c|c|c|}
\hline Title & $\begin{array}{l}\text { Production } \\
\text { year }\end{array}$ & $\begin{array}{l}\text { Supporting organization / } \\
\text { institution }\end{array}$ & $\begin{array}{c}\text { Location } \\
\text { (Department) }\end{array}$ & Type of film & $\begin{array}{l}\text { Type of } \\
\text { fishery }\end{array}$ & URL \\
\hline & & & & performance) & & a/bagre-rayado \\
\hline $\begin{array}{l}\text { Fúquene: una apuesta sustentable } \\
\text { (Fúquene: A sustainable bet) }\end{array}$ & 2017 & Humedales Foundation & Cundinamarca & Documentary & Inland & n.a. \\
\hline $\begin{array}{l}\text { Andalucía, un puerto sin pescadores } \\
\text { (Andalucía, a port without fishers) }\end{array}$ & 2013 & Cromatophoro corporation & Cesar & Documentary & Inland & $\begin{array}{l}\text { https://www.youtube.c } \\
\text { om/watch?v=Qd8I6j8g } \\
\text { Lqs }\end{array}$ \\
\hline $\begin{array}{l}\text { Pescadores de la Ciénaga del Sapo } \\
\text { (Fishers of the Ciénaga del Sapo) }\end{array}$ & 2017 & $\begin{array}{l}\text { Research group -Oralidad, } \\
\text { Narrativa Audiovisual y Cultura } \\
\text { popular en el Caribe Colombiano, } \\
\text { University of Magdalena }\end{array}$ & Magdalena & Music video & Inland & n.a. \\
\hline $\begin{array}{l}\text { La Agonía de la Ciénaga de San Silvestre } \\
\text { (The Agony of the San Silvestre's Lake) }\end{array}$ & 2017 & TvAgro & Santander & $\begin{array}{l}\text { TV show, not } \\
\text { TV news }\end{array}$ & Inland & $\begin{array}{l}\text { https://www.youtube.c } \\
\text { om/watch?v=WFn7jlQ } \\
\text { oqMY\&feature=youtu. } \\
\text { be }\end{array}$ \\
\hline $\begin{array}{l}\text { Redes del Pacífico (primera parte) } \\
\text { (Fishing nets of the Pacific (Part one) }\end{array}$ & 2012 & Cromatophoro corporation & $\begin{array}{l}\text { Cauca } \\
\text { Chocó } \\
\text { Valle del Cauca } \\
\text { Nariño }\end{array}$ & Documentary & $\begin{array}{l}\text { Coastal- } \\
\text { Marine }\end{array}$ & $\begin{array}{l}\text { www.youtube.com/wat } \\
\text { ch?v=aElel- } \\
\text { 4RDgs\&t=75s }\end{array}$ \\
\hline $\begin{array}{l}\text { De Faena, relatos de la vida en el Golfo de Urabá } \\
\text { (Fishing, life stories in the Gulf of Urabá) }\end{array}$ & 2017 & University of Antioquía & Antioquia & Documentary & $\begin{array}{l}\text { Coastal- } \\
\text { Marine }\end{array}$ & $\begin{array}{l}\text { https://www.youtube.c } \\
\text { om/watch?time_contin } \\
\text { ue=3\&v=Yj3pxpiY4FE } \\
\text { \&feature=emb_logo }\end{array}$ \\
\hline $\begin{array}{l}\text { Pescadores de Raya y Tiburón } \\
\text { (Sharks and rays fishers) }\end{array}$ & 2015 & $\begin{array}{l}\text { Research group -Oralidad, } \\
\text { Narrativa Audiovisual y Cultura } \\
\text { popular en el Caribe Colombiano, } \\
\text { University of Magdalena }\end{array}$ & Magdalena & Short film & $\begin{array}{l}\text { Coastal- } \\
\text { Marine }\end{array}$ & $\begin{array}{l}\text { https://www.youtube.c } \\
\text { om/watch?v=x5lwl_uD } \\
\text { ihY }\end{array}$ \\
\hline
\end{tabular}




\begin{tabular}{|c|c|c|c|c|c|c|}
\hline Title & $\begin{array}{l}\text { Production } \\
\text { year }\end{array}$ & $\begin{array}{c}\text { Supporting organization / } \\
\text { institution }\end{array}$ & $\begin{array}{c}\text { Location } \\
\text { (Department) }\end{array}$ & Type of film & $\begin{array}{l}\text { Type of } \\
\text { fishery }\end{array}$ & URL \\
\hline $\begin{array}{l}\text { Por una pesca de arrastre de camarón más } \\
\text { responsable y sostenible (primera parte) } \\
\text { (For a more responsible and sustainable shrimp } \\
\text { trawling (Chapter one)) }\end{array}$ & 2018 & TvAgro & Atlántico & $\begin{array}{l}\text { TV show, not } \\
\text { TV news }\end{array}$ & $\begin{array}{l}\text { Coastal- } \\
\text { Marine }\end{array}$ & $\begin{array}{l}\text { https://www.youtube.c } \\
\text { om/watch?v=vYHIARD } \\
\text { Ep4Y }\end{array}$ \\
\hline $\begin{array}{l}\text { Proceso de Consulta Previa DRMI Golfo de } \\
\text { Tribugá- Cabo Corrientes } \\
\text { (Prior consultation process in the DMRI Gulf of } \\
\text { Tribuga- Cabo Corrientes) }\end{array}$ & 2015 & $\begin{array}{l}\text { En Puja Communications } \\
\text { Collective }\end{array}$ & Chocó & Short film & $\begin{array}{l}\text { Coastal- } \\
\text { Marine }\end{array}$ & $\begin{array}{l}\text { https://www.youtube.c } \\
\text { om/watch?v=LKgQLL } \\
\text { ZsA_k }\end{array}$ \\
\hline $\begin{array}{l}\text { Criterios de pesca responsable } \\
\text { (Responsible fishing guidelines) }\end{array}$ & 2016 & $\begin{array}{l}\text { En Puja Communications } \\
\text { Collective } \\
\text { Marviva Foundation }\end{array}$ & Chocó & Short film & $\begin{array}{l}\text { Coastal- } \\
\text { Marine }\end{array}$ & $\begin{array}{l}\text { https://www.youtube.c } \\
\text { om/watch?v=JMOdls2 } \\
\text { 3a2c }\end{array}$ \\
\hline $\begin{array}{l}\text { Niños y jóvenes de Buenaventura cantan para } \\
\text { combatir la pesca ilegal } \\
\text { (Children and youngsters from Buenaventura sing to } \\
\text { fight illegal fishing) }\end{array}$ & 2015 & $\begin{array}{l}\text { National Authority for Aquaculture } \\
\text { and Fisheries - AUNAP } \\
\text { World Wildlife Foundation } \\
\text { Colombia }\end{array}$ & Valle del Cauca & Music video & $\begin{array}{l}\text { Coastal- } \\
\text { Marine }\end{array}$ & $\begin{array}{l}\text { https://www.youtube.c } \\
\text { om/watch?v=zjOQhbN } \\
\text { oWXU }\end{array}$ \\
\hline $\begin{array}{l}\text { Pensando colectivamente el manejo de la pesca } \\
\text { artesanal marina en Colombia } \\
\text { (Thinking collectively about the management of } \\
\text { small-scale marine fishing in Colombia) }\end{array}$ & 2015 & $\begin{array}{l}\text { National Fisheries and } \\
\text { Aquaculture Authority } \\
\text { Research group 'Sistemas } \\
\text { socioecológico para el bienestar } \\
\text { humano', University of Magdalena } \\
\text { Research group 'Evaluación y } \\
\text { Ecologia pesquera', University of } \\
\text { Magdalena } \\
\text { Squalus Foundation }\end{array}$ & $\begin{array}{l}\text { Atlántico } \\
\text { Córdoba } \\
\text { Chocó } \\
\text { La Guajira } \\
\text { Magdalena } \\
\text { Nariño } \\
\text { Valle del Cauca }\end{array}$ & Short film & $\begin{array}{l}\text { Coastal- } \\
\text { Marine }\end{array}$ & $\begin{array}{l}\text { https://www.youtube.c } \\
\text { om/watch?v=SHj5XPj } \\
\text { 9vTM\&t=72s }\end{array}$ \\
\hline
\end{tabular}




\section{Supplementary Material 2}

Complete list of drivers-pressures, impacts on and response to unwanted developments in the artisanal fishing sector of Colombia reported in the films. Source: Own elaboration

Note: CM- Coastal / Marine Fisheries; I - Inland Fisheries; T - Total

\begin{tabular}{|c|c|c|c|c|c|c|c|c|c|c|c|c|}
\hline System & PRESURES DRIVERS & $\mathrm{CM}$ & II & $T$ & IMPACTS & $\mathrm{CM}$ & II & $T$ & RESPONSES & CM & II & $T$ \\
\hline \multirow{6}{*}{ Ecosystem } & Alien species & 0 & 1 & 1 & Changes in fish species populations & 4 & 4 & 8 & Conservation projects & 1 & 1 & 2 \\
\hline & Climate change & 1 & 1 & 2 & Decreased water quality & 2 & 2 & 4 & Ecological restoration & 3 & 1 & 4 \\
\hline & Ecosystem / habitat degradation & 1 & 3 & 4 & Ecosystem / habitat degradation & 8 & 6 & 14 & Stop dumping toxic materials & 0 & 1 & 1 \\
\hline & Hydro-morphological alterations & 1 & 2 & 3 & Environmental destruction & 4 & 0 & 4 & Water management & 2 & 0 & 2 \\
\hline & Pollution & 5 & 7 & 12 & Impacts on endangered species & 2 & 0 & 2 & & & & \\
\hline & Waste management & 1 & 1 & 2 & Loss of ecological connectivity & 1 & 0 & 1 & & & & \\
\hline \multirow{10}{*}{ Society } & Civil armed conflict / Violence & 2 & 4 & 6 & $\begin{array}{l}\text { Cultural loss (identity, heritage, societal } \\
\text { relevance) }\end{array}$ & 4 & 2 & 6 & Alliances with social movements & 1 & 0 & 1 \\
\hline & Collision of interests & 1 & 0 & 1 & Consumption of unhealthy fish & 1 & 0 & 1 & Cultural revalorisation & 2 & 0 & 2 \\
\hline & Lack of environmental awareness & 3 & 1 & 4 & Decline in fisherfolks quality of life & 7 & 5 & 12 & Ecological justice & 1 & 0 & 1 \\
\hline & Lack of land planning & 1 & 0 & 1 & Eroded moral values on Mother Earth & 0 & 1 & 1 & Improved governance & 0 & 1 & 1 \\
\hline & Urbanisation & 1 & 0 & 1 & Health problems & 0 & 1 & 1 & Increase awareness & 2 & 2 & 4 \\
\hline & Weak institutions & 6 & 5 & 11 & Impacts on food security & 7 & 3 & 10 & Local resistance against extractivist projects & 1 & 0 & 1 \\
\hline & & & & & Institutional problems & 2 & 0 & 2 & Political participation & 1 & 0 & 1 \\
\hline & & & & & Issues on access to nat. res. (land, water) & 2 & 1 & 3 & Regulations / Law enforcement & 4 & 0 & 4 \\
\hline & & & & & Loss of subsistence capacity & 2 & 1 & 3 & Respect and love life and the environment & 2 & 2 & 4 \\
\hline & & & & & Social problems & 3 & 0 & 3 & Use of local ecological knowledge & 3 & 1 & 4 \\
\hline \multirow{6}{*}{ Economy } & $\begin{array}{l}\text { Economic activities incompatible } \\
\text { with fishing (general) }\end{array}$ & 3 & 4 & 7 & Decreasing income / jobs & 4 & 0 & 4 & Aquaculture & 1 & 0 & 1 \\
\hline & Energy crops & 0 & 1 & 1 & $\begin{array}{l}\text { Fisherfolks livelihoods no longer viable or } \\
\text { reduced }\end{array}$ & 5 & 6 & 11 & Compensation & 1 & 0 & 1 \\
\hline & Forestry /Logging & 2 & 0 & 2 & Poverty & 1 & 0 & 1 & Increase economic value & 1 & 0 & 1 \\
\hline & Global markets & 0 & 1 & 1 & & & & & Public investments & 0 & 1 & 1 \\
\hline & Hydropower & 0 & 1 & 1 & & & & & Responsible consumers & 1 & 0 & 1 \\
\hline & Illegal crops & 0 & 1 & 1 & & & & & Stop mega-projects & 1 & 0 & 1 \\
\hline
\end{tabular}




\begin{tabular}{|c|c|c|c|c|c|c|c|c|c|c|c|c|}
\hline & Infrastructures & 0 & 1 & 1 & & & & & & & & \\
\hline & Livestock & 1 & 0 & 1 & & & & & & & & \\
\hline & Oil/coal/ ore extraction & 1 & 2 & 3 & & & & & & & & \\
\hline & Unsustainable souvenirs & 1 & 0 & 1 & & & & & & & & \\
\hline \multirow{24}{*}{ Fishing } & Destructive / unselective fishing & & & & & & & & & & & \\
\hline & methods & 8 & 3 & 11 & Decreased fish catch (number, size) & 0 & 1 & 1 & Ban to capture of endangered species & 1 & 0 & 1 \\
\hline & High demand of fisheries & & & & & & & & & & & \\
\hline & resources & 1 & 0 & 1 & Decreasing fishing areas & 5 & 4 & 9 & Best practices for bottom trawling & 0 & 1 & 1 \\
\hline & Increasing fishing effort & 5 & 0 & 5 & Fisheries depletion & 6 & 0 & 6 & Co-management & 0 & 1 & 1 \\
\hline & Irresponsible fishing & 1 & 0 & 1 & High costs in fishing & 1 & 0 & 1 & Community Fishing agreements & 1 & 2 & 3 \\
\hline & Lack of surveillance / monitoring & 6 & 3 & 9 & Low fish quality & 1 & 1 & 2 & Controlled fishing in protected areas & 0 & 1 & 1 \\
\hline & Non-compliance of fishing & & & & & & & & & & & \\
\hline & regulations / bans & 1 & 0 & 1 & \multirow[t]{16}{*}{ Unsustainable use of fisheries resources } & \multirow[t]{16}{*}{3} & \multirow[t]{16}{*}{0} & \multirow[t]{16}{*}{3} & Fish restocking & 1 & 0 & 1 \\
\hline & Overfishing & 9 & 3 & 12 & & & & & Fishing ban / close season & 2 & 1 & 3 \\
\hline & & & & & & & & & Fishing management plan & 2 & 1 & 3 \\
\hline & & & & & & & & & Minimum catch size / Ban to juvenile catches & 2 & 2 & 4 \\
\hline & & & & & & & & & Monitoring / Surveillance & 1 & 1 & 2 \\
\hline & & & & & & & & & New / adapted fishing methods \& techniques & 3 & 1 & 4 \\
\hline & & & & & & & & & Participatory fishing management plans & 1 & 2 & 3 \\
\hline & & & & & & & & & Participatory workshops & 0 & 1 & 1 \\
\hline & & & & & & & & & Promote integral fishers & 3 & 0 & 3 \\
\hline & & & & & & & & & Reduce by-catches / Avoid discards / Ban & & & \\
\hline & & & & & & & & & shark finning & 1 & 1 & 2 \\
\hline & & & & & & & & & Responsible fishing & 4 & 1 & 5 \\
\hline & & & & & & & & & Spatial marine zoning & 1 & 0 & 1 \\
\hline & & & & & & & & & Traceability & 1 & 0 & 1 \\
\hline & & & & & & & & & Training in sustainable fishing practices & 0 & 3 & 3 \\
\hline & & & & & & & & & Zoning / Protected area & 0 & 2 & 2 \\
\hline None & & & & & & & & & None & 1 & 0 & 1 \\
\hline
\end{tabular}

